OECDpublishing

THE CAREER EFFECTS OF LABOUR MARKET CONDITIONS AT ENTRY

DAN ANDREWS

NATHAN DEUTSCHER

JONATHAN HAMBUR

DAVID HANSELL

OECD PRODUCTIVITY WORKING PAPERS

November 2020 No. 20 


\section{OECD PRODUCTIVITY WORKING PAPERS}

The OECD Productivity Working Papers are associated with the Global Forum on Productivity that provides a forum for mutual exchange of information and fosters international co-operation between public bodies with responsibility for promoting productivity-enhancing policies, including in undertaking joint policy analysis. It offers a platform for exchanging views, experiences and information, institutional and governance arrangements and government structures, with a view towards developing better policies. The Forum extends existing work in the OECD through a well-prioritised and coherent stream of analytical work serving the policy research needs of participants on the drivers of productivity growth.

This paper has been authorised for publication by Luiz de Mello, Director, Policy Studies Branch, Economics Department, Álvaro Santos Pereira, Director, Country Studies Branch, Economics Department, and Andrew Wyckoff, Director, Directorate for Science, Technology and Innovation.

OECD Productivity Working Papers should not be reported as representing the official views of the OECD or of its member countries. The opinions expressed and arguments employed are those of the author(s).

Comments on OECD Productivity Working Papers are welcome and may be sent to: productivity@oecd.org OECD Productivity Working Papers are published on: oe.cd/productivity

Series: OECD Productivity Working Paper Series

ISSN 2413-9424

Please cite this paper as:

Andrews, D., Deutscher, N., Hambur, J. and Hansell, D., "The career effects of labour market conditions at entry", OECD

Productivity Working Papers, 2020-20, OECD Publishing, Paris.

This document and any map included herein are without prejudice to the status of or sovereignty over any territory, to the delimitation of international frontiers and boundaries and to the name of any territory, city or area.

The statistical data for Israel are supplied by and under the responsibility of the relevant Israeli authorities. The use of such data by the OECD is without prejudice to the status of the Golan Heights, East Jerusalem and Israeli settlements in the West Bank under the terms of international law.

(C) OECD (2020)

You can copy, download or print OECD content for your own use, and you can include excerpts from OECD publications, databases and multimedia products in your own documents, presentations, blogs, websites and teaching materials, provided that suitable acknowledgment of OECD as source and copyright owner is given. All requests for commercial use and translation rights should be submitted to rights@oecd.org. 


\section{ABSTRACT/RÉSUMÉ}

\section{The career effects of labour market conditions at entry}

This paper explores the effects of labour market conditions at graduation on an individual's work-life over the following decade. Australians graduating into a state and year with a 5 percentage point higher youth unemployment rate can expect to earn roughly 8 per cent less in their first year of work and $31 / 2$ per cent less after five years, with the effect gradually fading to around zero ten years on. The magnitude of this effect varies according to the characteristics of the individual and the tertiary institution they attend. We then explore the mechanisms behind this scarring. Scarring partly reflects the subsequent evolution of the unemployment rate - the fact that unemployment shocks tend to persist - highlighting the potential for timely and effective macroeconomic stabilisation policies to ameliorate these scarring effects. More generally, job switching to more productive firms emerges as a key channel through which workers recover from adverse shocks that initially disrupt (worker-firm) match quality. We find some evidence that the speed of recovery has slowed since 2000 , which is consistent with the decline in labour market dynamism observed in Australia over that period.

JEL classification: E24, J62, J64.

Keywords: Wages, job mobility, job search.

\section{Les effets de la situation du marché du travail à l'entrée des individus sur leur carrière ultérieure}

Nous examinons dans ce document les effets de la situation du marché du travail au moment où un individu obtient son diplôme sur sa vie professionnelle au cours des dix années suivantes. Les Australiens qui obtiennent leur diplôme dans un État et au cours d'une année caractérisés par un taux de chômage des jeunes en hausse de 5 points de pourcentage peuvent s'attendre à voir leur niveau de rémunération amputé de $8 \%$ environ leur première année d'emploi, et de $3 \frac{1}{2}$ pour cent au bout de cinq ans, cet effet diminuant peu à peu jusqu'à s'annuler au bout de dix ans. L'ampleur de cet effet varie suivant les caractéristiques des individus et l'établissement d'enseignement supérieur fréquenté. Nous étudions ensuite les mécanismes qui déterminent ces effets de stigmate. Ceux-ci tiennent en partie à l'évolution ultérieure du taux de chômage - c'est-à-dire au fait que le choc subi par le chômage tende à perdurer ce qui souligne que des mesures de stabilisation macroéconomique efficaces adoptées en temps voulu peuvent atténuer ces effets de stigmate. De manière plus générale, il apparaît que changer d'emploi pour intégrer une entreprise plus productive constitue une des principales voies que peuvent emprunter les travailleurs pour surmonter les chocs négatifs qui dégradent initialement la qualité de l'appariement entre les actifs et les entreprises. Nos travaux montrent dans une certaine mesure que la vitesse à laquelle ces chocs peuvent être surmontés a diminué depuis 2000 , ce qui concorde avec la perte de dynamisme du marché du travail observée en Australie au cours de cette période.

Classification JEL : E24, J62, J64.

Mots clés : salaires, mobilité professionnelle, recherche d'emploi. 


\section{Table of contents}

THE CAREER EFFECTS OF LABOUR MARKET CONDITIONS AT ENTRY

1. Introduction

2. Macroeconomic context and literature $\quad 7$

3. Data 9

3.1. Australian Longitudinal File on Individuals (Alife) 9

3.2. HECS/HELP data 10

3.3. Pay-As-You-Go (PAYG) Summary Statements 10

3.4. Business Activity Statements (BAS) 10

$\begin{array}{ll}\text { 4. Empirical framework } & 10\end{array}$

5. Results 13

5.1. Threats to identification 17

5.2. Heterogeneity 20

6. Mechanisms 22

6.1. Are job ladders harder to find?

7. Conclusion 26

References 28

Annex A. Summary Statistics $\quad 30$

Annex B. Non-graduate results 33

Annex C. Dynamic Model 34

Annex D. Heterogeneous Effects 36

\section{Tables}

Table 1. Effect of a 1 percentage point increase in the youth unemployment rate on annual earnings and employment

Table 2. Effect of a 1 percentage point increase in the youth unemployment rate on postgraduate enrolments and emigration

Table A.1. Average summary statistics for wage and salary income by state, 1991-2017. 30

Table A.2. Average number of graduates by gender and state, 1991 to $2017 \quad 30$

Table B.1. Effect of a 1 percentage point increase in the youth unemployment rate on annual earnings and employment for graduates and non graduates

Table D.1. Effect of a 1 percentage point increase in the youth unemployment rate on annual earnings for different groups (\%) 


\section{Figures}

Figure 1. Historical aggregate and youth unemployment rates — annual data 8

Figure 2. Youth unemployment and future wages outcomes 11

Figure 3. Stylised example of experience profiles, wages by years of experience 12

Figure 4. Local unemployment and future wages purged of cohort, experience and business cycle 14

Figure 5 . Effect of a 5 percentage point increase in the local youth unemployment rate by years since graduation

Figure 6. Effect of a 1 percentage point increase in the local youth unemployment rate by years since graduation for different periods

Figure 7. Effect of a 1 percentage point increase in the youth unemployment rate on annual earnings by years since graduation - differing subpopulations

Figure 8. Effect of a 1 percentage point increase in the local youth unemployment rate by years since graduation for different periods

Figure 9 . Effect of a 1 percentage point increase in the local youth unemployment rate by years since graduation

Figure 10. Effect of a 1 percentage point increase in the local youth unemployment rate by years since graduation

Figure 11. Job-switching rates by age group and educational attainment

Figure A.1. Number of Graduates: Tax data versus Department of Education data

Figure A.2. Deviation of state youth unemployment rate from national rate De-meaned; percentage point deviation

Figure A.3. Young Workers Share of Workforce by Firm Age

Figure C.1. Effect of a 1 percentage point increase in the local youth unemployment rate by years since graduation 


\title{
THE CAREER EFFECTS OF LABOUR MARKET CONDITIONS AT ENTRY
}

\author{
By Dan Andrews, Nathan Deutscher, Jonathan Hambur and David Hansell ${ }^{1}$
}

\section{Introduction}

1. Across OECD countries, there is a growing recognition that young people bore the brunt of the labour market adjustment to the Global Financial Crisis (GFC; OECD 2016). The subdued recovery of youth labour markets over the past decade raises the prospect that the crisis may have induced scarring effects, for example through poor initial firm-worker matching and the atrophying of skills. In this regard, empirical studies spanning North America, Japan and Europe have demonstrated that poor early labour market experience, particularly entering into the labour market during a downturn, can reduce earnings for up to ten years after graduation (Kahn, 2010; Oreopolous et al 2012). While the macroeconomic consequences of the GFC were far milder for Australia, the performance of the youth labour market has remained a concern for policymakers (Dhillon and Cassidy 2018; Borland and Coelli 2020), exacerbated by the current COVID-19 pandemic and associated economic fallout.

2. Indeed, if similar scarring dynamics are at play in Australia, there is a risk that the sharp rise in unemployment associated with COVID-19 may have long-lasting effects, even as cyclical conditions pick up and the influence of the virus subsides. But evidence on the aforementioned scarring phenomenon is limited for Australia. ${ }^{2}$ Accordingly, this paper explores the effects of labour market conditions at graduation upon an individual's work-life over the following decade. We utilise micro-aggregated data on individual wages of most graduates from 1991 to 2017, merged with qualifications drawn from ATO data on HECS/HELP loans. We then exploit the variation within and between state/territory youth unemployment rates to estimate how local labour market conditions at the time of graduation shape the subsequent earnings and employment profiles of workers. To isolate this mechanism, the model controls for other factors that would influence a graduate's earning and employment trajectories, such as the national

\footnotetext{
${ }^{1}$ The paper was produced while the authors worked together in the Macroeconomic Modelling and Policy Division of the Australian Treasury. Dan Andrews currently works at the OECD and all other authors remain at the Treasury. Correspondence: dan.andrews@oecd.org. Nathan.Deutscher@treasury.gov.au, Jonathan.Hambur@treasury.gov.au, David.Hansell@treasury.gov.au. The authors thank Robert Breunig, Jeff Borland, Jessica Hua, David Lowe, Meghan Quinn, Tomoko Hashizume, Nick Stoney, Nicholas Twaddle, Luke Willard for helpful advice, comments and suggestions. The support of Andrew Carter, Justin Holland, Logan McLintock, Matt Power and Julia Rymasz in the curation, clearance and provision of the aggregated data on which this paper's analysis is based is greatly appreciated. The views expressed in this paper are those of the authors and do not necessarily reflect those of The Australian Treasury or the Australian Government.

2 In a recent contribution, Borland (2020) provides evidence from HILDA data showing a strong association between the unemployment rate at the time at which a cohort of young people complete full-time education and the employment-to-population rate of that cohort in the following three years.
} 
business cycle, and changes in the national higher education system that could lead to differences in the unobserved characteristics of graduating cohorts.

3. Our baseline estimates from this static model imply that a 5 percentage point rise in the state youth unemployment rate - a typical contractionary episode in our data - is associated with a decline in earnings of 8 per cent in the initial year and $3 \frac{1}{2}$ per cent after five years, before fading to around zero ten years on. Estimates suggest a corresponding decline in the employment-to-population ratio of 31/2 per cent in the initial year and $3 / 4$ per cent after five years, with a negligible effect ten years on. These effects are broadly similar in magnitude to those uncovered by comparable international studies.

4. We show that shocks which hit workers at the start of their careers are more important than those that hit later. The heightened exposure of young workers to shocks has been attributed to a number of factors including: $l$ ) their need to sort into well-matched jobs in the formative years of their careers (e.g. Topel and Ward 1992); ii) the inability of new entrants to shelter in existing jobs; iii) the so-called last-in, first-out phenomenon with respect to labour adjustment; iv) the greater cyclicality of young firms, who tend to employ young workers (e.g. Davis and Haltiwanger 2019; Andrews 2019); and v) greater exposure to psychological scarring and signaling effects given the lack of past employment history.

5. One identification concern is that the contemporaneous variation in the unemployment rate might be correlated with other factors that influence subsequent earnings, such as emigration or further study choices that affect the composition of the graduate cohort, or the future unemployment rate. To address these concerns, we first show that shocks to the youth unemployment rate do not have a meaningful impact on rates of further study or emigration, suggesting that the results are unlikely to be driven by selection effects. We then go on to estimate a dynamic model that controls for persistence in youth unemployment rates. This yields qualitatively similar - albeit somewhat more modest - results to our baseline model, reflecting the fact that the evolution of the unemployment rate following the initial shock partly shapes the earnings-experience profile. This highlights the potential role for timely and effective macroeconomic stabilisation policies which, by supporting a rapid recovery in the labour market, can reduce any scarring purely associated with a more drawn-out recovery. The remaining component of scarring is best thought of as something then experienced by individuals exposed to the initial adverse shock, but no longer facing adverse macroeconomic conditions.

6. We then explore heterogeneous effects - initially with respect to the characteristics of the individuals and institution - in order to better understand the underlying mechanisms at work. We find that individuals graduating with an honours (or other postgraduate) degree are less affected by scarring than those with a bachelor's degree. The same is true for graduates of Group of Eight universities compared to graduates from other universities. These results are consistent with international evidence which suggests that the careers of more advantaged individuals are less likely to be disrupted by adverse labour market shocks. That said, while we find evidence of scarring for young individuals who do not attend university, these effects appear to be more modest than for university graduates. This suggests that the scarring mechanism underlying our results may relate to poor match quality and/or human capital depreciation two factors which may be less relevant for lower-skilled workers. Finally, we find labour market scarring is more persistent for women than it is for men.

7. We find a key role for firms in the operation of the scarring mechanism, with implications for match quality. Graduates that enter during a weaker economic environment tend to join (or remain at) lower productivity firms, suggesting that adverse shocks undermine match quality. This effect - which is more pronounced for women - persists for a number of years. Given the close link between wages and firm productivity (Treasury 2017; Andrews et al, 2019), this result helps explain why our scarring effects are, on average, estimated to be long-lasting but not permanent.

8. Labour mobility emerges as a key margin for understanding the impact of the initial shock and recovery process. Individuals that graduate in weaker economic times initially exhibit lower job switching rates. This is consistent with a mechanism whereby graduates keep their part-time university job for longer 
and the observed rise in the graduates since the GFC that are seeking - but not currently in - fulltime work (Dhillon and Cassidy, 2019). But over time, switching rates for this group rise relative to the control group - those that graduate in stronger economic times - which allows such workers to move to higher productivity firms and better paying jobs. This is consistent with the idea that job switching is an important mechanism to undo the damage of initial poor match quality (Oreopolous et al, 2012). Women have less elevated switching rates in the years following entry into a weak labour market than men, which may keep them trapped in low productivity firms for longer and explain their more persistent scarring.

9. Finally, we show that these scarring effects are more prominent and permanent for individuals who graduated in the post-2000 period. This is consistent with the decline in job switching - which has been particularly apparent for young and highly educated groups - which provides less scope to undo poor initial (firm) match quality. One implication is that structural reforms that remove barriers to labour mobility are likely to reduce the consequences of graduating in a recession, suggesting an important complementarity between macroeconomic and structural policy in addressing the short- and longer-run impacts of labour market shocks.

10. The paper proceeds as follows. Section 2 discusses the macroeconomic context and existing literature. Section 3 describes the underlying data and Section 4 outlines the econometric framework. Section 5 then presents the baseline results and Section 6 explores the underlying mechanisms. The final section discusses the broader implications of the results and identifies avenues for future research.

\section{Macroeconomic context and literature}

11. Young people in Australia and across other advanced economies are typically more subject to cyclical volatility in the labour market (Figure 1): youth unemployment rates rise and fall more markedly in busts and booms than the aggregate unemployment rate. The experience of the Global Financial Crisis (GFC) was no different, with youth unemployment rising by around 3 percentage points in Australia and 5 percentage points across the OECD. Since then, the youth labour market has been relatively slow to recover, generating substantial concern among policymakers (OECD 2016).

12. In Australia, while the rise in youth unemployment was less pronounced than the OECD as a whole, the youth labour market has remained a topic of substantial interest to policymakers. Dhillon and Cassidy (2018) document key trends that point to spare capacity in the youth labour market, including elevated levels of unemployment, underemployment and disengagement from the labour force. This has been reflected in a widening earnings gap between young and old workers - indeed a range of studies have highlighted that weak wage and income growth following the GFC has been particularly pronounced for youth (Treasury 2017; PC 2018). As Dhillon and Cassidy (2018) note, there is the potential for both cyclical and structural factors to be at play in the youth labour market; with structural factors including mismatch between the skills youth have and those employers want, but also potential scarring from earlier labour market downturns. 
Figure 1. Historical aggregate and youth unemployment rates — annual data

Panel A: Australia

Panel B: OECD Average
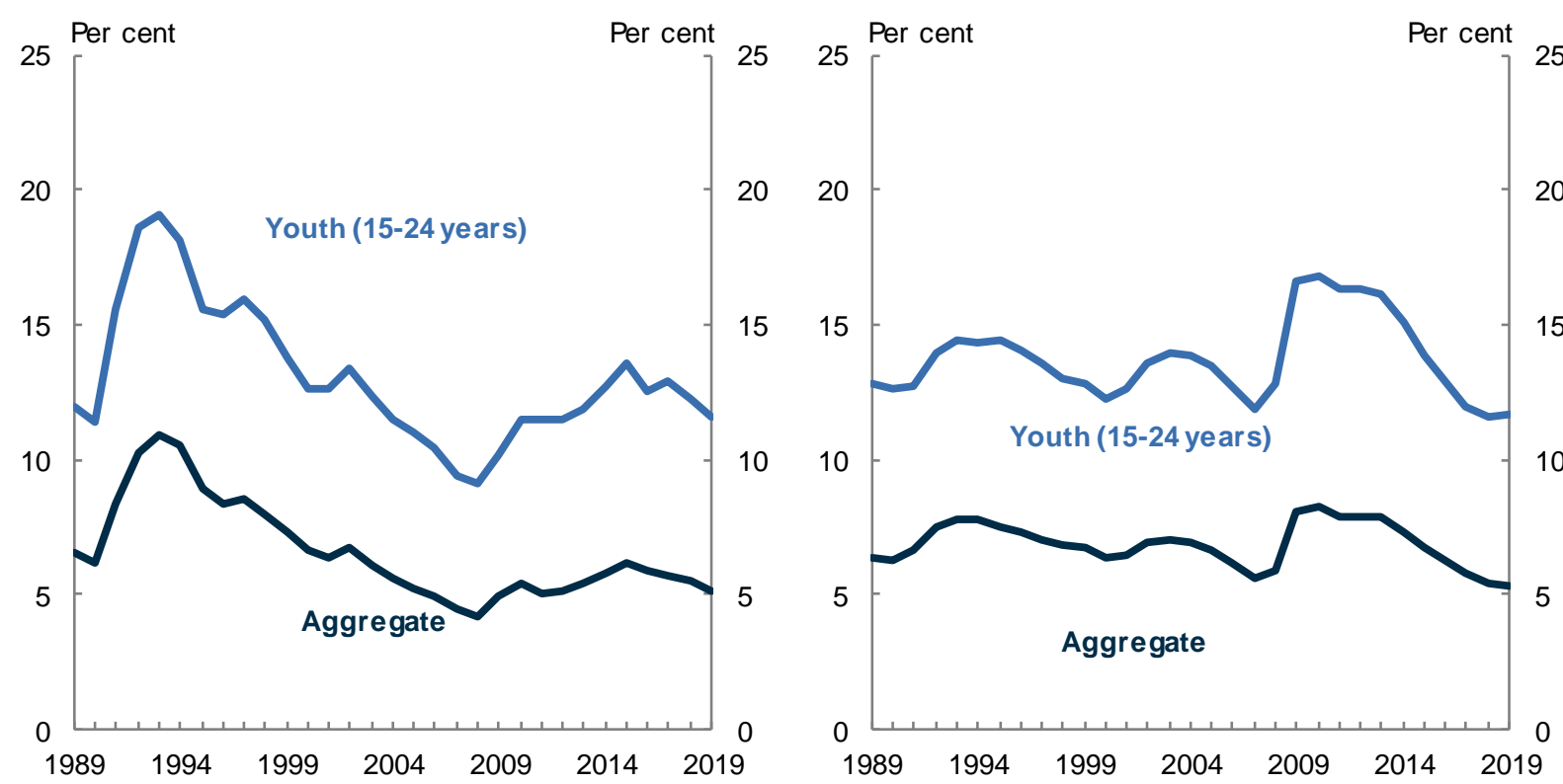

Note: Presents the aggregate and youth (15-24 years) unemployment rate by calendar year.

Source: ABS Labour Force Release Cat No. 6202.0; OECD.

13. Given their greater sensitivity to changing economic conditions (Figure 1), those graduating in a recession likely face worse career prospects in the near term. ${ }^{3}$ It is less clear whether this initial setback has lasting consequences, though there are a range of reasons to think that it might. For example, the human capital of recent graduates may depreciate if their skills become redundant or are lost while they are not being put to use in a well-matched job. After an initial setback, climbing back up the career ladder will take time, and may be difficult if employers fail to recognise the role of bad luck in early career struggles. These initial setbacks may be particularly damaging given the critical role of the early phase of the career - with estimates that almost 80 per cent of lifetime wage increases occur within the first decade of an individual's career (Murphy and Welch 1990). Finally, there may be 'psychological' scarring with graduates adjusting down their aspirations when faced by a shock during a particularly formative period. ${ }^{4}$

14. The international literature finds negative and somewhat persistent effects for those graduating in a bad labour market. Those graduating in a recession typically earn less and often work less than those graduating in better years, with these effects typically lasting up to ten years. Scarring effects along these lines have been documented in the United States (Kahn 2010; Altonji et al 2016; Schwandt and von Wachter 2019), Japan (Genda et al 2010), Canada (Oreopoulos et al 2012), Austria (Brunner and Kuhn 2014), Sweden (Kwon et al 2010) and Norway (Raaum and Røed 2006). Those graduating in a recession typically end up in worse-performing firms, with the more advantaged graduates subsequently catching up through job switching (Oreopoulos et al 2012). More specialised studies highlight how labour market

\footnotetext{
${ }^{3}$ There are a number of factors that can explain why youth are particularly vulnerable to labour market downturns. New entrants to the labour market do not have an existing job to shelter in, and those who have only recently taken a job may be among the first to lose them.

${ }^{4}$ A growing literature on habit formation finds that experiences in formative years can have a lasting effect on later life outcomes. For example, workers who live through stock market downturns tend to be less willing to take on financial risk (Malmendier and Nagel 2011),
} 
conditions at entry can shape workers in more fundamental ways - for example, managers who enter during recessions become CEOs more quickly, but at smaller firms and with more conservative management styles (Schoar and Zuo 2017).

15. These studies sit in the context of a longer and more generalised literature of hysteresis in labour markets, which explores the tendency for transitory adverse shocks to the actual unemployment rates to be reflected in a higher equilibrium unemployment rate (Blanchard and Summers 1986; Ball 2009). While initial historical accounts (e.g. Fernald et al 2017) dismiss the relevance of hysteresis for understanding the sluggish post-2009 output recovery in the United States, this view has been challenged by more recent granular studies, including some emphasising graduating in a recession as an important mechanism (Yagan 2019; Rothstein 2019).

16. Against this backdrop, this paper provides an Australian perspective on hysteresis, through the lens of those graduating into weak youth labour markets. This represents an important addition to the literature for local policymakers, especially in light of the recent COVID-19 shock. More generally, it contributes to the international literature by helping further our understanding of the extent to which experiences of labour market scarring are universal versus a function of a country's labour market institutions and structures.

\section{Data}

17. We use custom aggregations of de-identified tax data to identify the effect of labour market conditions at graduation on later career outcomes. These aggregations contain the average outcomes for individuals by graduation cohort and state, for each of the first ten years of their subsequent working lives. For most of the analysis, we use data from 1990-91 to 2017-18, focusing on cohorts that graduated between 1988-89 and 2012-13. Analysis using business related-outcomes, such as switching and labour productivity, uses data beginning in 2000-01.

18. The underlying microdata are from a prototype longitudinal linked employee-employer dataset held by the Australian Taxation Office (ATO), built in collaboration with the Australian Treasury (see Andrews et al, 2019). This dataset links personal income tax data from the Australian Longitudinal File on Individuals (Alife), education loan data (HECS/HELP), payment summaries issued by businesses to their employees and Business Activity Statements (BAS).

\subsection{Australian Longitudinal File on Individuals (Alife)}

19. Alife spans the period 1990-91 to 2017-18 and covers all Australian taxpayers. ${ }^{5}$ It contains financial and demographic variables that appear on individual tax returns, such as personal income, and place of residence. To illustrate this coverage, Table A1 in Annex A shows the average of various summary statistics for personal income by state/territory over the period 1990-91 to 2016-17.

20. We use salary and wage income from these returns as our measure of wages. Since we have the population of graduates from the HECS-HELP data irrespective of whether they file a tax return, we can calculate employment rates as the proportion of the graduating cohort who report non-zero salary and wages in a given year.

\footnotetext{
${ }^{5}$ A small number of individuals, such as well-known individuals who requested anonymity and defence force members are excluded; however these exclusions do not limit the representatives of the sample.
} 


\subsection{HECS/HELP data}

21. In 1988-89, the Australian federal government introduced fees for university education, which if deferred resulted in a debt known as Higher Education Contribution Scheme (HECS) debt. Due to further higher education reforms, debt after 2004-05 was incurred through a different scheme: the Higher Education Loan Program (HELP).

22. The ATO and Department of Education jointly administer the HECS/HELP scheme, and so the ATO receives data relevant to tertiary debt transactions, such as course and provider codes, debt incurred each semester and indexation payments, which they can match to their Alife database. Over 90 per cent of domestic students incur a HECS/HELP debt, meaning that a very large share of graduates entering the Australian labour market are covered by this data. ${ }^{6}$ Combining these data with the ALIFE data allows us to observe both where workers graduate, and where they end up working.

23. For our analysis we need to be able to identify when workers graduated. Until the introduction of the Higher Education Information Management System (HEIMS) in 2004-05, no degree completion indicators are available in the administrative data. As such, we have to impute completion indicators by observing when students stop incurring new HECS/HELP debt for each degree level. Some sample statistics on the number of graduates are included in Table A2 of Annex A.

24. In order to differentiate between different degree types and universities, we map the course and provider codes included in the data using a concordance provided by the Department of Education. Missing concordances are imputed by text mining the degree name.

\subsection{Pay-As-You-Go (PAYG) Summary Statements}

25. Since 2000-01, all employers are required by law to issue annual payment summaries to their employees. These contain unique identifiers for both employees and employers, which serves as the spine for the linking of employee and employer data, such as Alife and BAS. Further they permit us to calculate the number of employees for each business, which we use in our measure of labour productivity, and the rate of job switching, which we observe when employees change their main employer.

\subsection{Business Activity Statements (BAS)}

26. All businesses registered for GST purposes must submit monthly, quarterly or annual BAS to the ATO. We use total sales and non-capital purchases from these forms to derive value-added, which we then use to construct measures of employer labour productivity: value-added per employee.

\section{Empirical framework}

27. The aggregated data provides suggestive evidence for labour market scarring in the early years of an individual's career. In Figure 2 we show the mean earnings of graduation cohorts at various points in their working life, alongside the youth unemployment rate at the time of graduation. The three sharpest rises in youth unemployment rates - in the early 1990s, and early and late 2000s - all coincide with flat growth in subsequent earnings. This is most apparent in initial graduate earnings, but there are suggestive echoes in later years. In particular, earnings for these same cohorts in 2 and 4 years' time, indicated in the solid and dashed orange lines respectively, also appear to suffer relative to earlier cohorts.

\footnotetext{
${ }^{6}$ See for example:

https://docs.education.gov.au/system/files/doc/other/2018_section_5_-_liability_status_categories_0.pdf)
} 
Figure 2. Youth unemployment and future wages outcomes

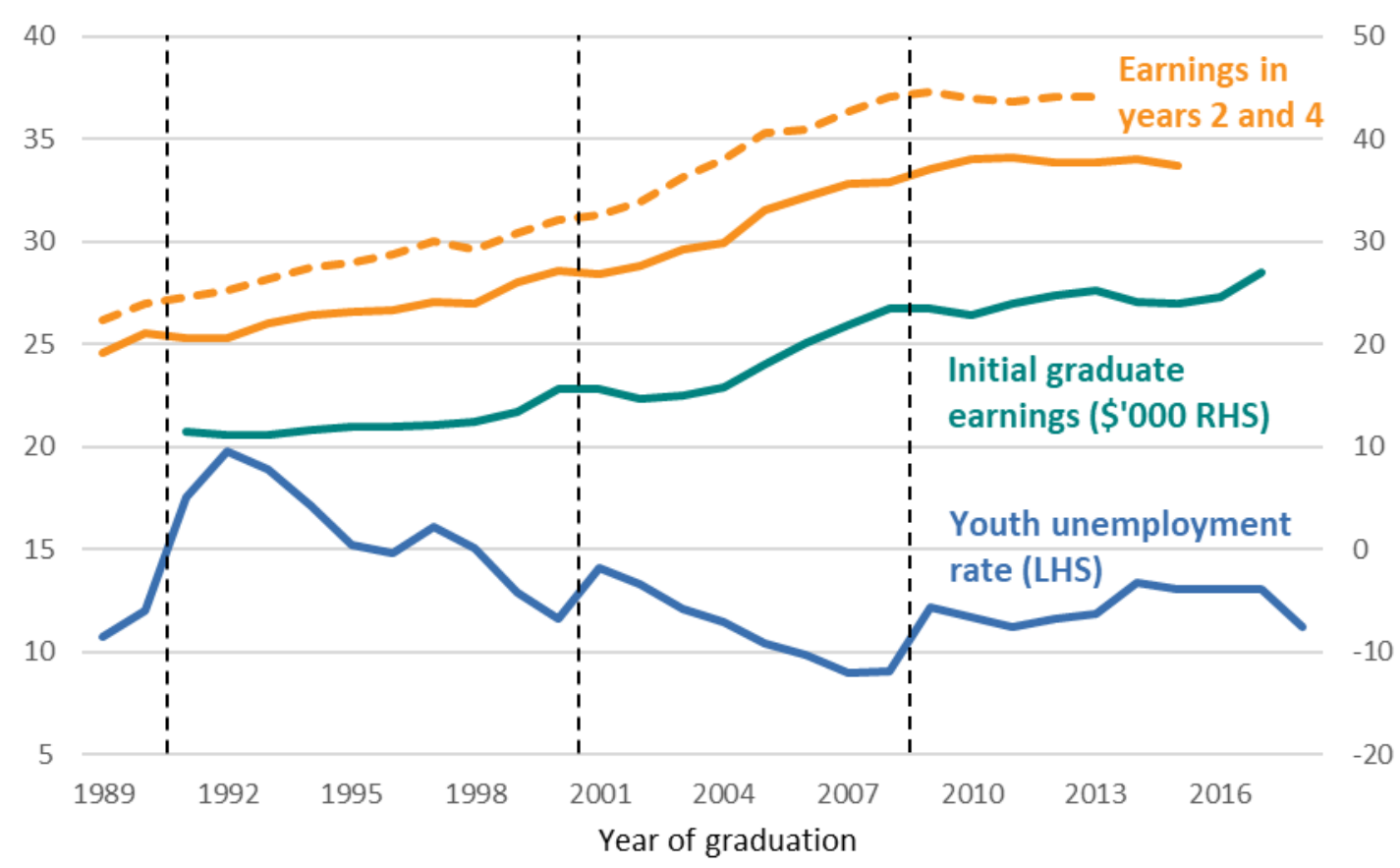

Note: The chart shows the mean earnings after 0,2 and 4 years of potential experience, by graduation cohort, alongside the national youth unemployment rate at the time of graduation. Based on ALIFE micro-aggregates and ABS Labour Force Release Cat No. 6202.0.

28. Ultimately, we are trying to identify the effect of changes in labour demand at graduation on labour market outcomes of workers. In doing so, we need to abstract from any cohort-specific labour supply changes, such as those that might be associated with changes in the national higher education system.

29. To do so, we follow some of the existing literature by exploiting variation in labour market strength over time and across regions (Oreopoulos et al 2012; Yagan 2019). In particular, we use state-year level variation in youth unemployment rates. In doing this, we ask whether those graduating in states with high youth unemployment relative to the national average in that year, and state average over time, do any worse in subsequent years. As shown in Annex A Figure A2, there have been substantial variations in youth unemployment rates over time between states. We use this variation to identify the effects of labour demand on outcomes, while abstracting from broader changes in cohort-specific labour supply.

30. The particular regression we use as our baseline is based on Oreopoulos et al (2012):

$$
\bar{y}_{c, s, t}=\alpha+\beta_{e} * I(t-c=e) * U R_{c, s, 0}+\phi_{t}+\theta_{s}+\gamma_{e}+\chi_{c}+X_{c e}+\varepsilon_{c s t}
$$

where $\bar{y}_{c s t}$ is the mean log annual earnings in year $t$ for all those graduating in year c and state $\mathrm{s}$. These graduates are defined as having potential experience $\mathrm{e}=\mathrm{t}-\mathrm{c}$. We restrict attention to the first decade of the working life $(\mathrm{e}=0, \ldots, 10)$. The key independent variable is $U R_{c, s, 0}$ - the average youth unemployment rate in the year and state of graduation. ${ }^{7} I(t-c=e)$ is an indicator that takes on the value 1 if the worker is of experience $e$, and 0 otherwise. The coefficients of interest are the $\beta_{e}$; these are intended to pick up any

\footnotetext{
${ }^{7}$ While youth unemployment rates are available at higher frequencies and finer geographies, we use the average at a state-year level given uncertainty in the timing of when graduates will search for a job. Tests with a variety of alternate unemployment rates all yielded fairly consistent results.
} 
scarring effects arising from labour market conditions at graduation and how they vary over the subsequent decade $\left(\beta_{0}, \ldots, \beta_{10}\right)$. They will capture variation in labour outcomes for the cohort that is correlated with the local labour strength on graduation. Each of the coefficients captures the relationship with outcomes $e$ years later, allowing us to trace out the effects over the first 10 years of workers' careers.

31. The intuition behind this specification - that we use in the stylised example in Figure 3, which is not based on real data - is as follows. We can think of the wages for a group of workers reflecting four factors. The first is the period or year. In any given year, wages for all workers might be higher or lower, reflecting national factors such as the business cycle or inflation. We account for these factors with the year dummies $\phi_{t}$. The second factor is the state. Some states might have persistently higher or lower earnings and youth unemployment rates, which we account for with the state dummies $\theta_{s}$. The third factor is the worker's experience. Workers' wages tend to increase over their careers as they gain experience. As such, workers' wages tend to follow an experience profile, such as the stylised one shown in Figure 3 Panel A. We capture this experience profile in the model by including dummies for the worker's experience $\gamma_{e}$.

\section{Figure 3. Stylised example of experience profiles, wages by years of experience}

Panel A: Stylised shift in national cohort

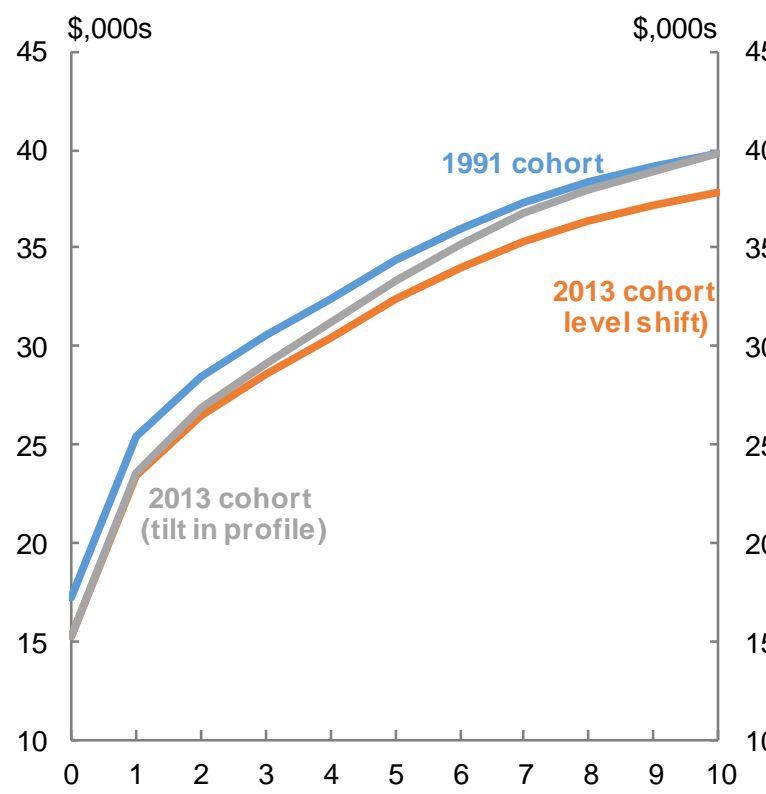

Panel B: Stylised effect of local labour market

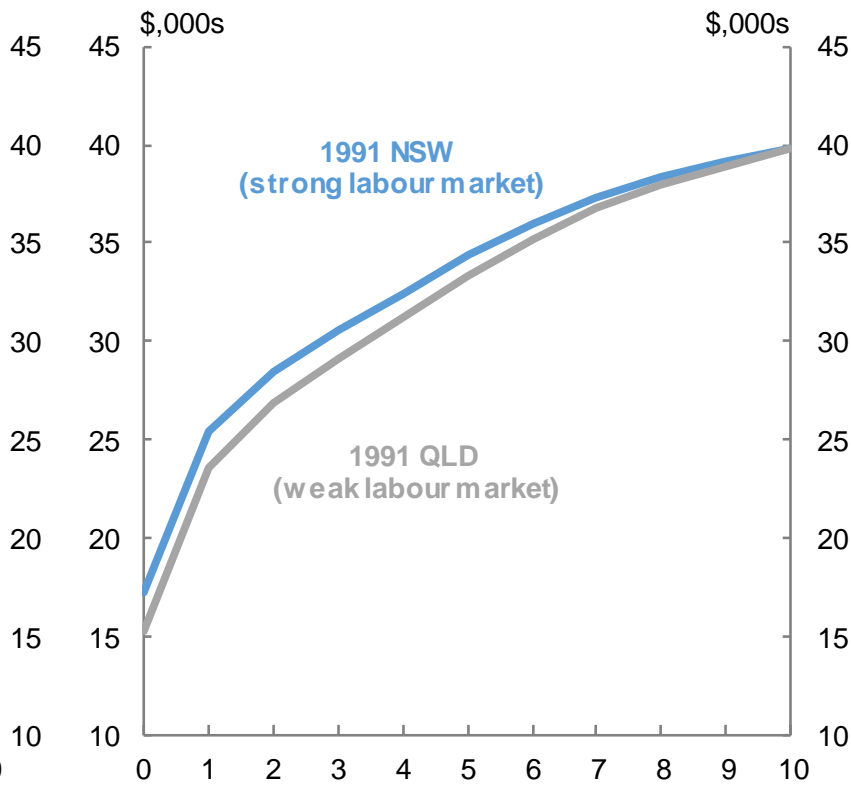

Note: Both panels show a stylised example of worker experience profiles by plotting expected wages for different years of working experience. Panel A demonstrates a change in the (national) cohort effects due, for example, to an expansion in the higher education system between 2010 and 2012. Panel $B$ demonstrates variation in profiles within cohort, based on differential labour market strength across states.

32. The final factor is the cohort. There might be differences between groups of workers that enter the labour market at different times, which cause the experience profile for these workers to look different to those of other workers. Put more precisely, there might be cohort-specific labour supply differences that affect cohort experience profiles. 
33. We might be particularly concerned about nation-wide factors associated with changes in the higher education system over time. ${ }^{8}$ For example, the expansion of the higher education system could mean that later graduate cohorts are, all else equal, more likely to work in lower paying jobs. As such, the experience profile for these workers might be consistently lower than earlier cohorts (Figure 3 Panel A orange line). We can capture this through the cohort dummies, $\chi_{c}$. It is also possible that these factors could affect the shape and slope of the experience profile, rather than just the level (Figure 3 Panel A grey line), and we allow for this using various controls interacting cohort and experience $X_{c e}$.

34. Having controlled for all of these factors, what is left are differences in experience profiles for given cohorts across states (Figure 3 Panel B). We identify those differences that are associated with initial labour demand using the local youth unemployment rate $U R_{c s 0}$. The coefficients on these variables are our parameters of interest, as they capture the relationship between initial labour market strength and later labour market outcomes.

35. As noted, our identification comes from differences in labour market conditions across states for given graduation cohorts. The main threat to this identification is that there are some unobserved cohort-state-specific unobserved characteristics correlated with local labour market conditions that affect the earnings-experience profile. For example, we might be concerned that workers change their labour supply decisions and stay in school longer if local labour market conditions are weaker. We consider these threats to credible identification in Section 5.

\section{Results}

36. By way of introduction, Figure 4 presents graphical evidence on the relationship between youth wages five years after graduation ( $y$-axis) and the state youth unemployment rate at the time of graduation ( $x$-axis). The red line is a linear regression fit of $y$ on $x$, purged of national level cyclical shocks, cohort and experience effects. For ease of observation, we split the sample of the $x$ variable into 20 bins of equal size, and each point in the scatter plot gives the sample mean of $y$ for each bin.

37. A strong negative relationship emerges, which we interpret as evidence that graduating in a weaker (stronger) labour market carries persistent adverse (beneficial) effects on earnings, at least five years on. The relationship is also relatively linear: it is not driven purely by lower or higher than typical youth unemployment rates. This suggests we will be identifying a general effect of labour market conditions at entry rather than the effect of graduating in a particular point of the cycle, be it a boom or a bust.

\footnotetext{
${ }^{8}$ For example, between 2010 and 2012, the Australian Government removed the caps on undergraduate university places by introducing a demand-driven system for domestic students. The series of changes to the system led to a pick-up in university enrolments rates for younger people. For other related changes to the education system, see Dhillon and Cassidy (2018).
} 
Figure 4. Local unemployment and future wages purged of cohort, experience and business cycle

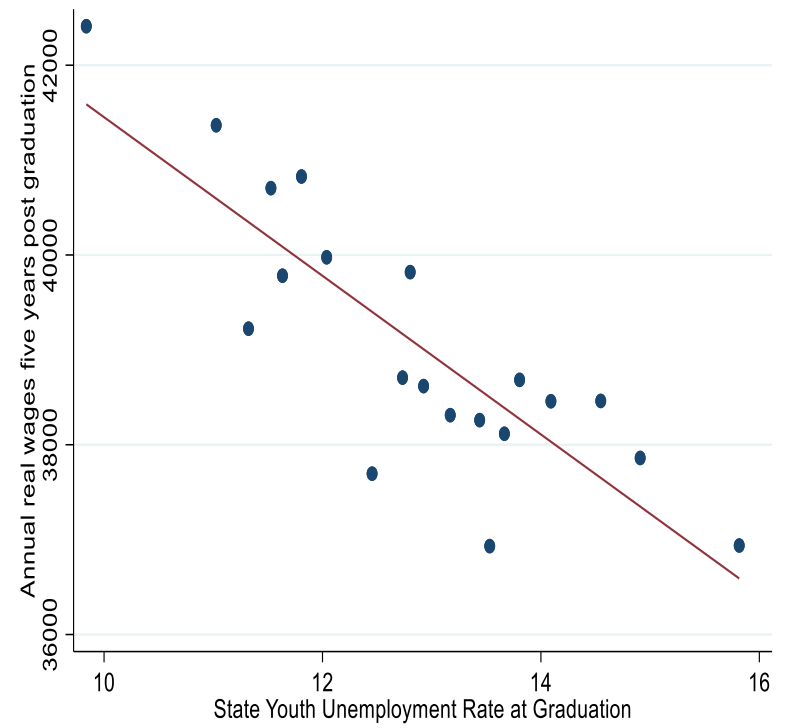

Note: The chart shows the state youth unemployment rates against wage outcomes five years later. Red line is line of best fit. Relationship purged of cohort, experience and business cycle effects. Based on ALIFE micro aggregates.

38. Table 1 Panel A shows the results from our baseline regression of wages on unemployment at graduation. Columns 1-3 show the result from models using the state youth unemployment rate where we allow increasingly flexible differences between cohorts across time. Doing so tends to lead to slightly smaller and less persistent estimates of the effects initial labour market conditions on wages.

39. That said, even in our preferred specification (column 3 ), which allows the experience profile to differ flexibly year-to-year, there does appear to be a persistent effect of initial labour market conditions on wages. A one percentage point rise in the youth unemployment rate at graduation is associated with wages that are $11 / 2$ per cent lower initially, but are still around 3/4 per cent lower five years later. Worker wages then catch up over the ensuing years to be about the same as other workers after 10 years.

40. Columns 4-6 show similar results using the national youth unemployment rate, rather than the state youth unemployment rate. In these models our key independent variable - the youth unemployment rate - now varies only by cohort. As a result, we are unable to include cohort fixed effects to control flexibly for any changes in the earnings ability or trajectories of graduating cohorts over time. Instead, we now use linear or quadratic cohort trends. In the most flexible model we also allow a quadratic cohort trend in experience premia that allows cohorts to differ not just in their earnings level but their earnings-experience profiles. In this national model, we find that the unemployment rate at entry has a larger initial effect, but the effect is less sustained. This is somewhat surprising, as we might expect the national business cycle to be more important than the local cycle, for example given that people are not able to avoid a national shock by simply moving interstate. 
Table 1. Effect of a 1 percentage point increase in the youth unemployment rate on annual earnings and employment

\begin{tabular}{|c|c|c|c|c|c|c|}
\hline \multirow[b]{2}{*}{ Years since graduation } & \multicolumn{3}{|c|}{ State Unemployment Rate } & \multicolumn{3}{|c|}{ National unemployment rate } \\
\hline & (1) & (2) & (3) & $(4)$ & (5) & (6) \\
\hline \multicolumn{7}{|l|}{ Panel A Wage outcomes (\%) } \\
\hline 0 & $\begin{array}{c}-3.0^{* * *} \\
(0.2)\end{array}$ & $\begin{array}{c}-1.7^{\star \star \star} \\
(0.2)\end{array}$ & $\begin{array}{c}-1.6^{\star \star *} \\
(0.2)\end{array}$ & $\begin{array}{c}-3.3^{\star \star \star} \\
(0.2)\end{array}$ & $\begin{array}{c}-3.6^{\star \star \star} \\
(0.3)\end{array}$ & $\begin{array}{c}-2.22^{\star \star *} \\
(0.4)\end{array}$ \\
\hline 5 & $\begin{array}{l}-0.4^{* *} \\
(0.2)\end{array}$ & $\begin{array}{c}-0.6^{\star * *} \\
(0.2)\end{array}$ & $\begin{array}{c}-0.7^{\star * *} \\
(0.2)\end{array}$ & $\begin{array}{c}0.0 \\
(0.2)\end{array}$ & $\begin{array}{c}0.1 \\
(0.2)\end{array}$ & $\begin{array}{l}-0.1 \\
(0.2)\end{array}$ \\
\hline 10 & $\begin{array}{c}-0.7^{\star \star \star} \\
(0.2)\end{array}$ & $\begin{array}{l}-0.4^{\star *} \\
(0.2)\end{array}$ & $\begin{array}{l}-0.2 \\
(0.2)\end{array}$ & $\begin{array}{l}-0.4^{*} \\
(0.2)\end{array}$ & $\begin{array}{c}0.0 \\
(0.2)\end{array}$ & $\begin{array}{c}0.2 \\
(0.2)\end{array}$ \\
\hline \multicolumn{7}{|c|}{ Panel B: Employment outcomes (ppt) } \\
\hline 0 & $\begin{array}{c}-0.78^{\star \star \star} \\
(0.05)\end{array}$ & $\begin{array}{c}-0.74^{\star \star \star} \\
(0.05)\end{array}$ & $\begin{array}{c}-0.69^{\star \star \star} \\
(0.05)\end{array}$ & $\begin{array}{c}-1.0^{\star \star *} \\
(0.06)\end{array}$ & $\begin{array}{l}-1.2^{\star \star \star} \\
(0.08)\end{array}$ & $\begin{array}{c}-1.30^{\star \star \star} \\
(0.10)\end{array}$ \\
\hline 5 & $\begin{array}{c}-0.14^{\star *} \\
(0.04)\end{array}$ & $\begin{array}{c}-0.12^{\star \star \star} \\
(0.04)\end{array}$ & $\begin{array}{c}-0.13^{\star \star \star} \\
(0.05)\end{array}$ & $\begin{array}{l}-0.4^{\star \star \star} \\
(0.05)\end{array}$ & $\begin{array}{c}-0.35^{\star \star \star} \\
(0.05)\end{array}$ & $\begin{array}{c}-0.26^{\star * \star} \\
(0.05)\end{array}$ \\
\hline 10 & $\begin{array}{l}-0.06 \\
(0.05)\end{array}$ & $\begin{array}{l}-0.05 \\
(0.04)\end{array}$ & $\begin{array}{l}0.10^{\star \star} \\
(0.05)\end{array}$ & $\begin{array}{c}-0.27^{\star \star \star} \\
(0.06)\end{array}$ & $\begin{array}{l}-0.06 \\
(0.08)\end{array}$ & $\begin{array}{c}-0.19^{\star \star \star} \\
(0.07)\end{array}$ \\
\hline \multicolumn{7}{|l|}{ Specification } \\
\hline Experience FE X cohort & & $x$ & & & & $x$ \\
\hline Experience FE X cohort FE & & & $x$ & & & \\
\hline Cohort FE & $x$ & $x$ & $x$ & & & \\
\hline Order of cohort trend & & & & 1 & 2 & 2 \\
\hline $\mathrm{N}$ & 2008 & 2008 & 2008 & 2008 & 2008 & 2008 \\
\hline
\end{tabular}

Note: Shows the coefficients on youth unemployment rate at graduation, at zero, five and ten years post graduation. Based on a regression of mean log annual earnings or proportion of employed workers on the youth unemployment rate in the state and year of graduation, with year, state, experience and cohort fixed effects. In column (2) we interact experience fixed effects with the cohort, allowing for linear trends in experience premia. In column (3) we have experience cohort fixed effects. Columns (4) (6) present national models. Standard errors, clustered at the state cohort level, are presented in brackets. ${ }^{*},{ }^{* *},{ }^{* *}$ indicate statistical significance at the 10,5 and 1 per cent level, respectively.

41. So far we have focused on wage outcomes. One concern is that many workers may be unable to find jobs, or choose to remain outside of the labour force, in response to the weaker labour demand. This type of sample selection will lead to an understatement of the effects on unemployment on wage outcomes.

42. To consider this, we run a similar model but using the proportion of the graduating population that are employed as the LHS variable. This approach will allow us to understand the effect of labour market strength on the extensive employment margin. This is highly relevant, given unemployed workers may be more likely to have human capital depreciation, and given they may receive unemployment benefits.

43. The results are outlined in Table 1 panel B. Using our preferred specification (column 3), a 1 percentage point increase in the state youth unemployment rate is associated with a $3 / 4$ percentage point decline in the employment-to-population ratio for the group. This effect is again moderately persistent, with evidence of statistically significant declines in employment again up to around 5 years after graduation. The finding with respect to employment is a bit more persistent than has been found in other papers, such as Oreopolous et al (2012) and Altonji et al (2016).

44. Interestingly, using the national unemployment rate yields a larger and potentially more persistent effect. This contrasts with the wages model. One explanation could be the relative persistence of local and 
national business cycles. In response to a more transient shock, firms may be less willing to adjust headcounts and may prefer to adjust wages and hours for existing workers, due to costs in hiring and firing. As such, if state cycles tend to be shorter and less persistent, as suggested by in Annex A Figure A2, we might expect a larger adjustment on the wage margin than on the employment margin in the state models compared to the national model.

45. To put these metrics into context, from 2008 to 2015, Victoria's youth unemployment rate went from around 10 per cent to around 15 per cent. All else equal, this 5 percentage point increase would be associated with wages that were 8 per cent lower on impact, and around $31 / 2$ per cent lower after 5 years. (Figure 5 Panel A). The employment rate would be around $31 / 2$ percentage points lower on impact, and still around $3 / 4$ percentage point lower 5 years later (Figure 5 Panel B).

Figure 5. Effect of a 5 percentage point increase in the local youth unemployment rate by years since graduation

Panel A: Effect on wages

Panel B: Effect on employment-to-population

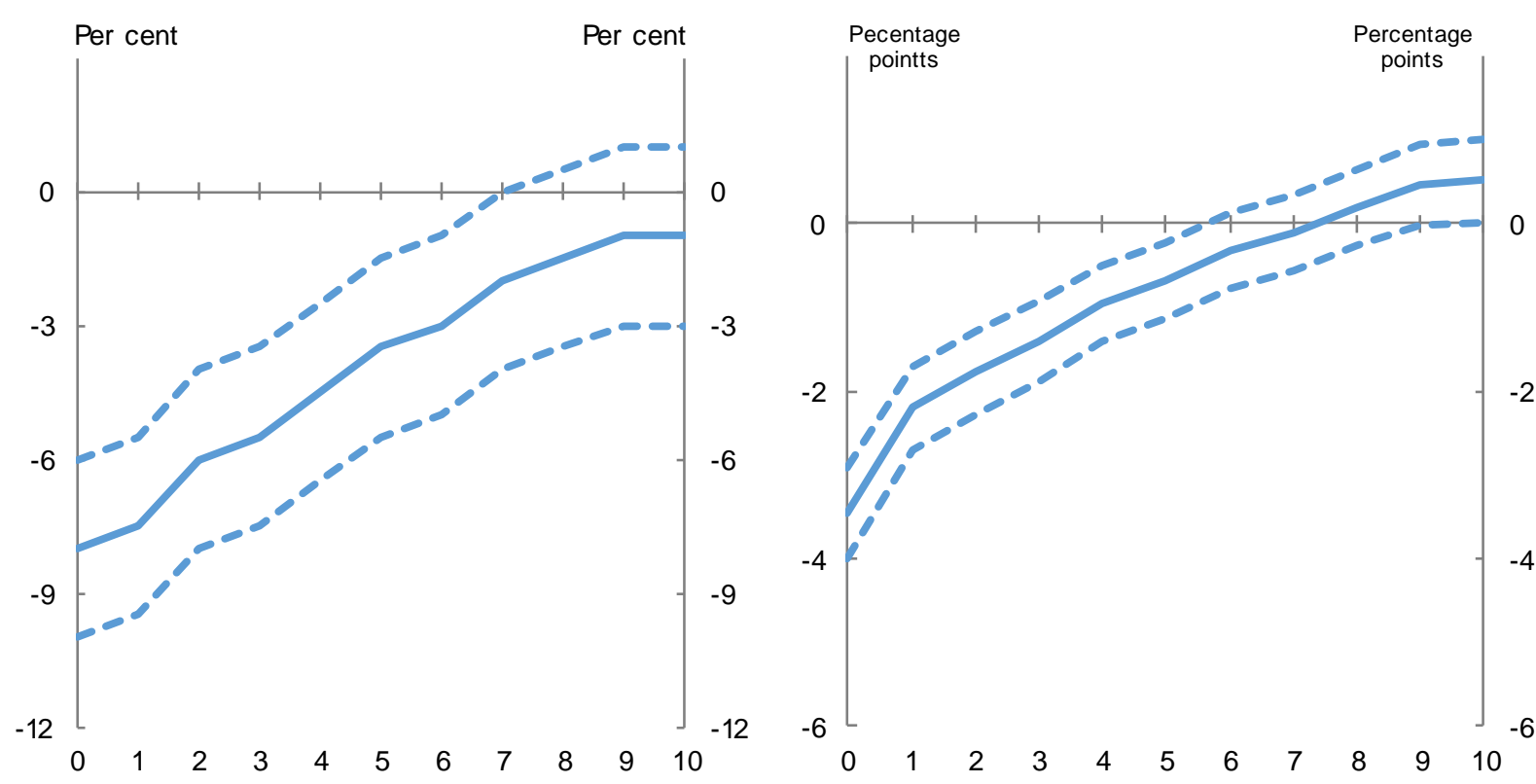

Note: Shows estimated effect of a 5 percentage point increase in the state youth unemployment rates, based on column 3 in Table 1. Dotted lines are 2 s.e. confidence bands.

46. So far we have focused on workers that graduate from university, but a weak labour market is also likely to affect young workers without a university degree. To examine this we run similar regressions, but for a sample of young workers without university degrees, who we treat as having entered the labour market at the age of 18 years. This sample includes all workers with no university degree that turned 18 in the relevant year and state, and that have filed a tax return at some point and so enter the ALIFE dataset. Similar to the graduate analysis, workers with no salary or wages income are treated as not employed.

47. The results indicate that the effect on non-graduates is smaller and less persistent, consistent with the findings of Hershbein (2012) (Annex B). This might suggest that some of the mechanisms through which weak labour markets affect worker outcomes are less relevant for non-graduates, such as bad matching (see below) or human capital depreciation. But we cannot rule out that it may also reflect the greater difficulty in defining labour market entry for non-graduates. 


\subsection{Threats to identification}

\subsubsection{Persistence in the unemployment rate}

48. As discussed in Oreopoulos et al (2012) the estimates from the baseline model capture the average change in earnings from graduating in a weak labour market, given the regular evolution of the regional unemployment rate faced afterwards. Put another way, the estimates capture both the direct effects of labour market conditions at entry, but also the fact that if the youth unemployment rate at entry increases, it will tend to remain elevated for a period and this will weigh on outcomes in its own right.

49. Any persistence in the unemployment rate is a legitimate part of the long-run effect of short-run labour market shocks, and so is of interest. But we might also be interested in isolating the direct effect of labour market conditions at entry, as this can help us to understand the channels through which short-run shocks propagate to the long-run. Moreover, it can provide guidance for policy. If most of the effect comes through persistent weak labour market conditions, this would suggest subsequent stabilisation polices should be highly effective in ameliorating long-run effects. If most of the effect reflect the initial shock, other polices around skills, re-training and efficient labour markets, might be more important.

50. To test this, we adopt the dynamic model of Oreopoulos et al (2012). This model is similar to the baseline model. But instead of simply tracing out the effect of the initial state unemployment rate over time, we control for the full unemployment history faced by workers, allowing each to have persistent effects on wage and employment outcomes. In doing so, we allow for the possibility that workers may have moved interstate by using the current state of residence for all unemployment rates aside from those on graduation. ${ }^{9}$ We also take the slightly simpler approach where we account for contemporaneous conditions using either state-year fixed effects, or the contemporaneous unemployment rate interacted with years of experience.

51. For both approaches, we also follow Oreopoulos et al (2012) and group unemployment rates over two year periods. That is, we trace out the effects of the average youth unemployment rate experienced over year 0 (entry) and 1 in the labour market. This helps to address the fact that unemployment rates in adjacent years are highly correlated, making it hard to identify the model results when including all years. That said, the results are fairly similar when we include yearly unemployment rates instead, with initial unemployment rates estimated to be a little less important. ${ }^{10}$

52. Figure 6 contains the key results of these models, while the more detailed results are in Annex C. Once we account for later conditions (blue line), the importance of the initial youth unemployment rate is diminished somewhat for both the wage and employment margins. The effect is reduced by about $1 / 3$ in each of the first five years for wages, and by slightly less for employment for year 2-4. However, there still appears to be a significant and persistent effect of initial unemployment rates for around 4-5 years following graduation on both wages and employment.

53. The analysis also shows that shocks which hit workers at the start of their careers are more important than those that hit a few years later. This is evident in the smaller and less persistent effect of unemployment rates 4-5 years later on both wages and employment (Annex $C$ Figure $C 1$ ). It indicates that

\footnotetext{
${ }^{9}$ This will accurately capture the labour market conditions faced by graduates if they move at most once, and that move immediately follows graduation. Graduation is indeed a point in the lifecycle when individuals are particularly mobile and responsive to distant labour market opportunities (Wozniak 2010). While ideally we would trace the entire geographic history of each worker we are limited by the need to have sufficiently large micro-aggregates to avoid the potential for recognition.

${ }^{10}$ As robustness, we also used the aggregate, rather than youth, unemployment rate as it may be more relevant in later years, and tried excluding students that were over 25 on graduation. The key conclusions are robust to these choices, though the exact magnitudes and dynamics can vary.
} 
what we are identifying is not simply the fact that weak labour markets are bad for all workers. Rather, what we are picking up is that they are particularly damaging for new graduates.

54. Overall then, the results suggest that at least part of the poor outcomes for graduates are associated with prolonged periods of weak labour markets, suggesting an important role for stabilisation policy. But there also appear to be some persistent effects from the initial weak labour market. We consider potential mechanisms for such a phenomena in section 6.

Figure 6. Effect of a 1 percentage point increase in the local youth unemployment rate by years since graduation for different periods

Panel A: Effect on wages

Panel B: Effect on employment

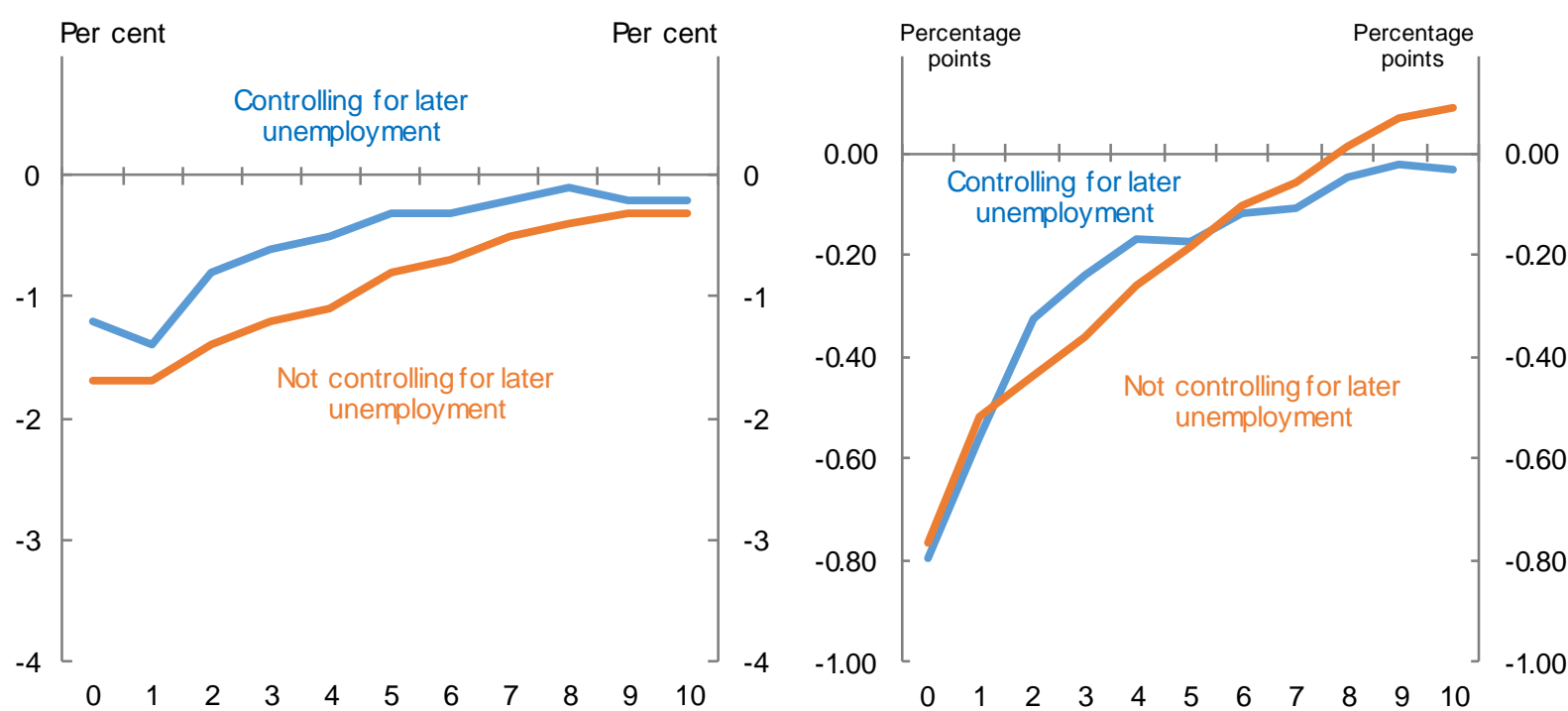

Note: Shows estimated effect of a 1 percentage point increase in the state youth unemployment rates on wages and employment from various models. 'Not controlling for later unemployment' series is taken from the static model, with unemployment rate at graduation replaced with the rate over the initial and first subsequent year. This is analogous to the 'Group_01 (no history)' series in Figure C1 of Annex C. 'Controlling for later unemployment' series comes from the full dynamic model, which incorporates the full labour market history of groups and allows these rates to have dynamic effects (this is referred to as “Group_01"in Figure C1 of Annex C).

\subsubsection{Selection mechanisms - education and emigration}

55. One way of framing the key assumption of our model is that there are no other factors that influence the labour market outcomes of those graduating in a given state and year, that are also correlated with the youth unemployment rate they faced at graduation. A standard concern in such settings is some kind of selection mechanism. For example, perhaps when faced with a high youth unemployment rate, individuals may choose to extend their studies or, if they enter the labour market, they may choose to emigrate. ${ }^{11}$ Both mechanisms could generate an association between the youth unemployment rate faced by a given group of graduates and their later labour market outcomes. In particular, if it is the potential high earners who are

\footnotetext{
${ }^{11}$ Of course, immigration may also respond to youth unemployment rates. If anything this would bias our estimates towards finding no scarring effect, to the extent that a higher youth unemployment rate in a given state and year results in less competition from immigrants for those graduating. Further, existing Australian evidence finds little evidence of an impact of immigration on the labour market outcomes of local workers, suggesting such bias is negligible (Brell and Dustmann 2019).
} 
able to continue into further study or emigrate, then this may lead to a compositional effect that drags down the observed outcomes of the graduation cohort in bad years.

56. In Table 2, we examine the potential for these selection mechanisms to bias our results by testing whether the youth unemployment rate is associated with either outcome - further study or emigration. In particular, we re-estimate the following variant of our baseline static model:

$$
y_{s t}=\alpha+\beta_{0} U R_{c s 0}+\phi_{t}+\theta_{s}+\varepsilon_{s t}
$$

where the outcome variable in the given state and year is either the natural logarithm of postgraduate enrolments, or the natural logarithm of the youth departures component of net overseas migration. ${ }^{12,13}$ In both cases, the coefficient can be interpreted as a semi-elasticity - the per cent response in the outcome variable to a one percentage point increase in the youth unemployment rate. To run a national variant of this model, we use the national youth unemployment rate and collapse the data to a national time series. As a result, we also drop the state and year fixed effects, but allow for a quadratic time trend.

57. For the regional model - drawing on idiosyncratic movements in state unemployment rates there is no indication that either enrolments in postgraduate study or departures respond to the youth unemployment rate. In both cases, the coefficient is of the 'wrong' sign and not statistically different from zero. In the national model, this is no longer the case - a higher youth unemployment rate is associated with a modest increase in enrolments in postgraduate study and departures. However, given the modest effect and low base rates of postgraduate enrolment and departures, the bias introduced by these mechanisms is almost certainly negligible. ${ }^{14}$

\section{Table 2. Effect of a 1 percentage point increase in the youth unemployment rate on postgraduate} enrolments and emigration

\begin{tabular}{lccccc}
\hline & \multicolumn{3}{c}{ Outcome } \\
\cline { 3 - 6 } & \multicolumn{2}{c}{ Enrolments } & \multicolumn{2}{c}{ Departures } \\
\hline Coefficient on youth & -0.009 & $0.018^{\star * \star}$ & & -0.011 & $0.021^{*}$ \\
unemployment rate & $(0.008)$ & $(0.005)$ & & $(0.009)$ & $(0.010)$ \\
& & & & & \\
Model & Regional & National & Regional & National \\
$\mathrm{N}$ & & & & \\
$\mathrm{R}^{2}$ & 144 & 18 & 120 & 15 \\
\hline
\end{tabular}

Note: Shows the coefficients on youth unemployment rate at graduation. Based on a regression of either the natural logarithm of postgraduate enrolments or of the youth departures component of net overseas migration on the youth unemployment rate in the given state and year, and year and state fixed effects (Regional model, columns (1) and (3)); or at a national level on the youth unemployment rate in the given year and a quadratic in year. Standard errors are presented in brackets. ${ }^{*},{ }^{* *},{ }^{* *}$ indicate statistical significance at the 10,5 and 1 per cent level, respectively.

\footnotetext{
${ }^{12}$ This is simply the baseline model for an outcome observed only in the initial year, when potential experience equals zero.

${ }^{13}$ We take the postgraduate enrolments from the higher education statistics collection maintained by the Department of Education, Skills and Employment (2020) and emigration from population statistics collected by ABS (2019).

${ }^{14}$ For example, suppose that 10 per cent of graduate cohort selects into further study/emigration. Then if a 1 percentage point rise in the youth unemployment rate lifted this by 2 per cent (to 10.2 per cent) and those newly selecting into further study/emigration would have earned twice as much as the average member of the cohort, then average earnings for the cohort would fall by only 0.2 per cent. This is much smaller than the initial earnings impact of $1 \frac{1}{2}$ per cent shown in Table 1, column (3).
} 


\subsection{Heterogeneity}

58. An emerging theme from the international literature is that not all graduates experience labour market scarring to the same extent. Oreopolous et al (2012) show that more advantaged graduates those predicted to have higher earnings based on their university and program of study - initially suffer less from graduating into a weak labour market, and also recover more quickly by moving to better firms. Similarly, Altonji et al (2016) find that graduates in majors that typically have higher wages are less sensitive to labour market conditions at graduation.

59. In Figure 7 and Annex D (Table D1), we explore heterogeneity in labour market scarring in the Australian context. Those graduating with an honours degree or higher (Panel A) or from Group of Eight universities (Panel B) appear less sensitive to labour market conditions at entry - the earnings effect is smaller and less persistent. This pattern of results suggests these more advantaged graduates are better able to avoid poor initial matches, and recover from them more quickly - consistent with the international literature discussed above. Similarly, older graduates - who may already have a foothold in the labour market - experience a much smaller shock (Panel C).

60. Finally, female graduates experience more persistent labour market scarring (Panel D). While initial earnings for men and women appear similarly sensitive to labour market conditions at entry, earnings effects ten years on are only apparent for women. Gender differences in labour market scarring have received little attention in the literature - indeed, many studies focus purely on male graduates. ${ }^{15} \mathrm{~A}$ notable exception is Hershbein (2012) who finds that, for high school students, graduating into a weak labour market is associated with persistently worse employment outcomes for women, but not for men. Whereas men are found to respond by enrolling in further study, women appear to temporarily substitute into home production. Household-level data would allow further examination of the role of household gender dynamics in our results; however, given the aggregated data available, we can only observe the resulting gender differences in earnings, employment and firm-level characteristics. ${ }^{16}$ As discussed below, job-switching is a key means of recovering from a bad initial match, and differences in job-switching between men and women are one potential explanation for differing experiences of labour market scarring.

\footnotetext{
${ }^{15}$ For example, male graduates are the focus of Kahn (2010) (United States), Genda et al (2010) (United States and Japan), Oreopoulos et al (2012) (Canada), Brunner and Kuhn (2014) (Austria).

${ }^{16}$ A number of studies highlight asymmetric responses by gender to more general labour market shocks that in part appear to stem from gender dynamics within the household - for example, in the Australian context, Foster and Stratton (2018) find that in households with more traditional gender role attitudes, men do less housework after losing their job, while their female partners do more.
} 
Figure 7. Effect of a 1 percentage point increase in the youth unemployment rate on annual earnings by years since graduation — differing subpopulations

Panel A: Bachelors v Honours+

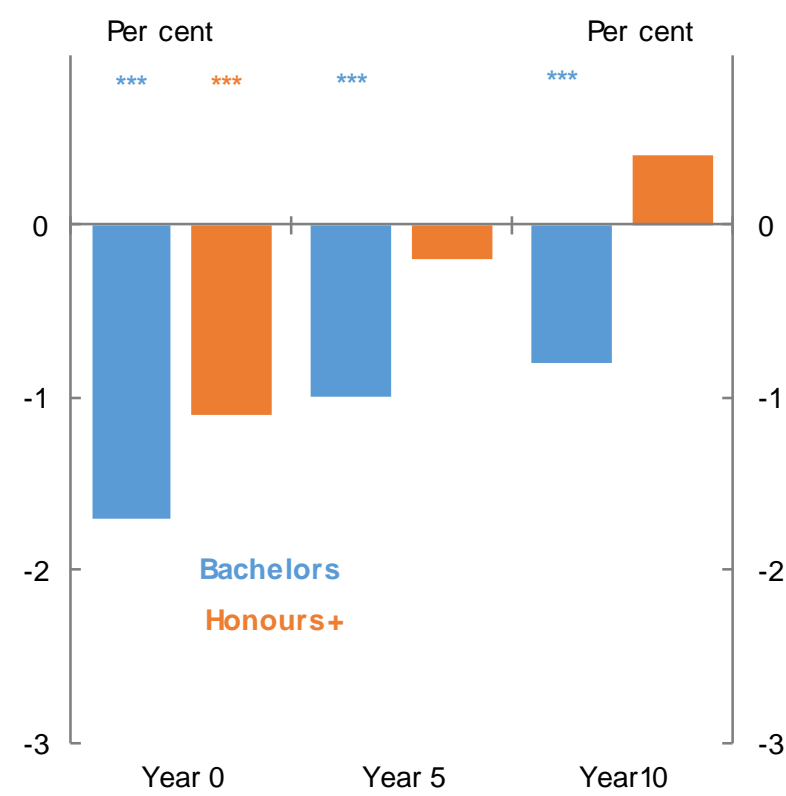

Panel C: Above and below 25
Panel B: G8 v non-G8

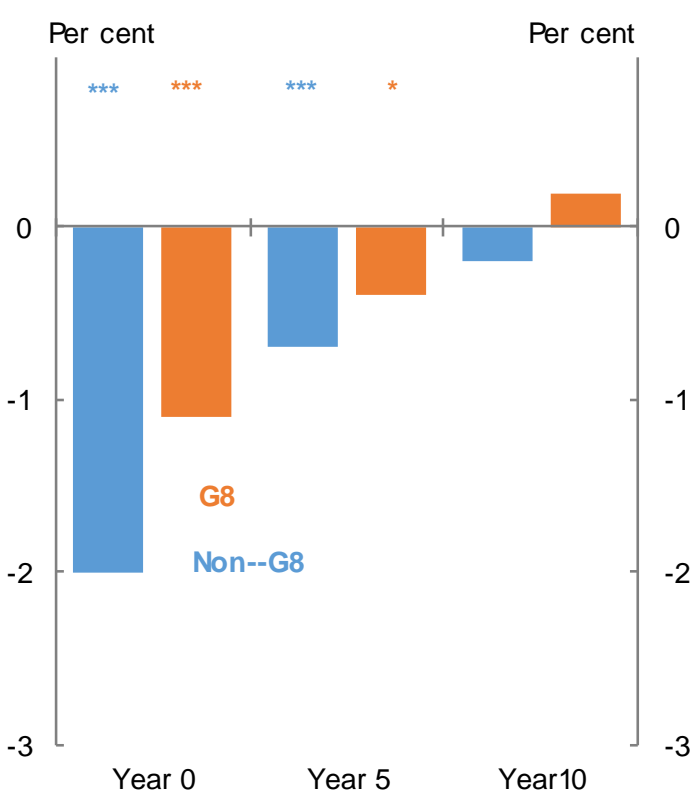

Panel D: Female v Male

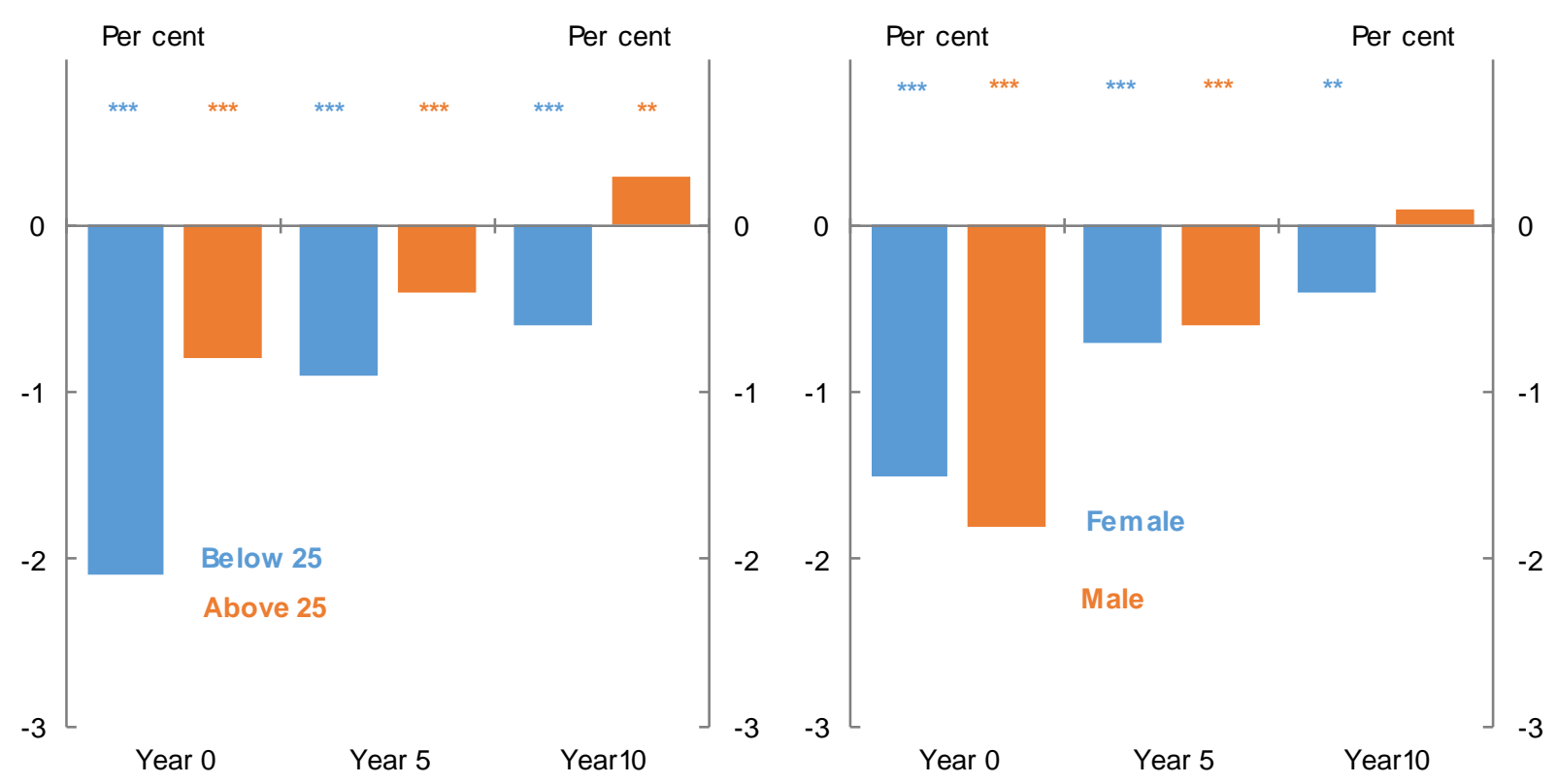

Note: Shows the estimated effect on wages of a 1 percentage point increase in the state youth unemployment rates on impact, and 5 and 10 years afterwards. These come from the static model outlined in Section 5 , run over different subsamples. Standard errors, clustered at the state cohort level, are presented in brackets. *,**,** indicate statistical significance at the 10,5 and 1 per cent level, respectively.

61. So far we have considered heterogeneity across different types of graduates. But we might also expect there to be differences in the effects of graduating into subdued labour markets across different periods, reflecting changes in labour markets and the education system.

62. To examine this we re-run the baseline model, but splitting the sample into those graduating in the 1990s versus those graduating in the 2000s. The results are summarised in Figure 8 and Table D1 of 
Annex D. Labour market conditions at graduation appear to have had a substantially less persistent effect on wages in the 1990s compared to the 2000s. The effects on the probability of employment also appear to be a bit less persistent in the medium-term. This finding is somewhat concerning, as it suggests that the recent period of weakness in youth labour markets could have more prolonged effects than past episodes of labour market scarring. ${ }^{17}$ To understand why experiences of labour market scarring might have changed we need to understand the mechanisms through which labour market conditions at graduation may produce lasting effects on labour market outcomes. We now turn to this question.

Figure 8. Effect of a 1 percentage point increase in the local youth unemployment rate by years since graduation for different periods

Panel A: Effect on wages

Panel B: Effect on employment

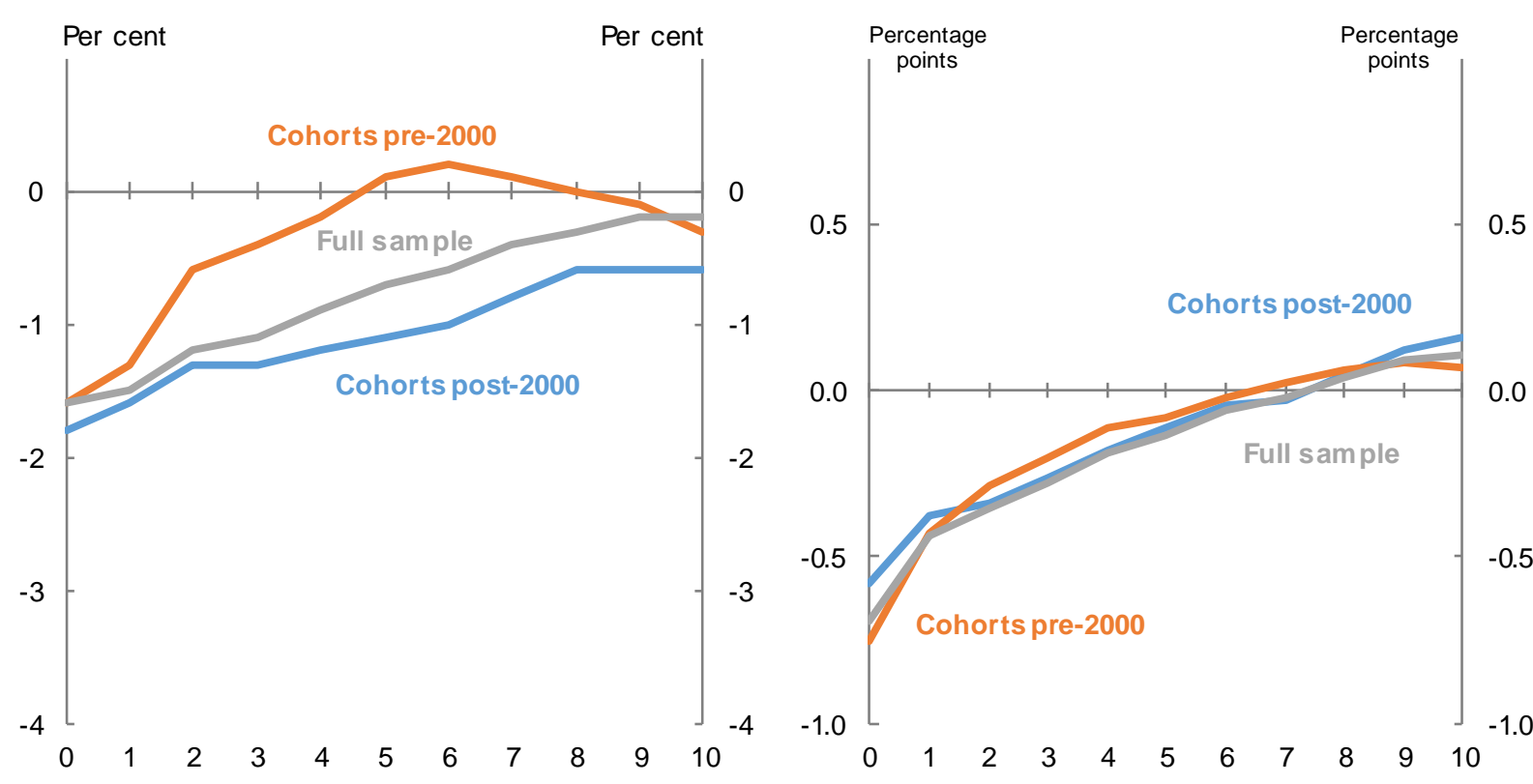

Note: Shows estimated effect of a 1 percentage point increase in the state youth unemployment rates on wages and employment for various sub samples. These come from the static model outlined in Section 5, run over different subsamples.

\section{Mechanisms}

63. The previous sections provided evidence that graduating into a weak local labour market can have fairly persistent effects on later labour market outcomes, particularly for younger graduates, women and graduates that are likely to have lower earning capacity. There are a number of potential mechanisms that could explain this relatively persistent effect that have been considered in the literature:

- Human capital destruction: Skills learnt at university could degrade relatively quickly if not used, leading to lower human capital and persistently weaker earnings. Similarly, time spent outside the labour force might mean workers lose time in which they could acquire valuable skills.

\footnotetext{
17 Models accounting for later labour market conditions also show this difference across samples, indicating we are not simply picking up a change in the persistence of the unemployment rate. Moreover, there is relatively little evidence that local business cycles have become more persistent since 2000.
} 
- Psychosocial scarring and signalling effects: Workers that fail to get a job, or a good job, upon graduation may reassess their expectations of their earning capacity, and therefore settle for lower paying jobs (e.g. Krueger and Mueller 2016). Similarly, employers may take the fact that a worker failed to get a job as a poor signal, and so may be less willing to hire them or pay them a high wage (e.g. Kroft et al 2013).

- Structural skills mismatch: To the extent that the labour market downturn has an industry specific aspect, graduates who trained to work in that industry may not have the skills demanded by the labour market. This could be particularly important if graduates had selected into that industry due to a previous boom (Hombert and Matray, 2019).

- Bad matching: During a downturn, it might be more difficult to find a job that is well suited to the worker. This could reflect the general weakness in the labour market, which lowers the number of 'good quality' job offers, but also potentially the pro cyclicality of such jobs due to differences across industries, and differences in the expected value and cost of training across the cycle (McLaughlin and Bils 2001; Kahn 2010). If it is relatively easy for workers to change jobs when the labour market recovers, these effects could be relatively short lived. But if there are structural impediments such as barriers to labour adjustment, firm entry or competition - then these effects could be relatively persistent.

64. Previous papers have found that bad initial matching can explain a large portion of the earnings losses for those graduating into a downturns (Brunner and Kuhn 2014; Oreopoulos et al 2012). Moreover, job switching, and moving up the so called job ladder, has been identified as a key mechanism through which workers can undo the initial effects of a bad match, especially for workers with higher earnings potential (Oreopoulos et al 2012).

65. To examine the role of initial match quality (and job switching), we re run our baseline model, but replacing the outcome variable with either the average labour productivity of firms that the graduates work for (or the proportion of graduates in a state cohort cell that switch jobs). In both cases, we are restricted to observing patterns over the 2000s - the period for which workers can be linked to firms and hence job switching behaviours and firm productivity can be observed.

66. As evident in Panel A of Figure 9, switching rates initially decline, likely reflecting the fact that graduates might find it harder to transition from their university jobs to new full time jobs. Switching rates then increase, relative to the switching experience profiles of other workers, as some of this initial poor matching is unwound. These results are qualitatively and quantitatively similar to those found in Oreopolous et al (2012). Consistent with the earlier analysis, graduates who enter labour markets during weak periods tend to work at less productive - and thus lower paying - firms (Figure 9, Panel B), given the strong link between wages and firm productivity (Treasury 2017; Andrews et al, 2019). This productivity 'gap' closes over time, which may reflect graduates moving to more productive firms, thereby undoing initial poor quality matches. 
Figure 9. Effect of a 1 percentage point increase in the local youth unemployment rate by years since graduation

Panel A: Effect on switching rates

Panel B: Effect on employer productivity
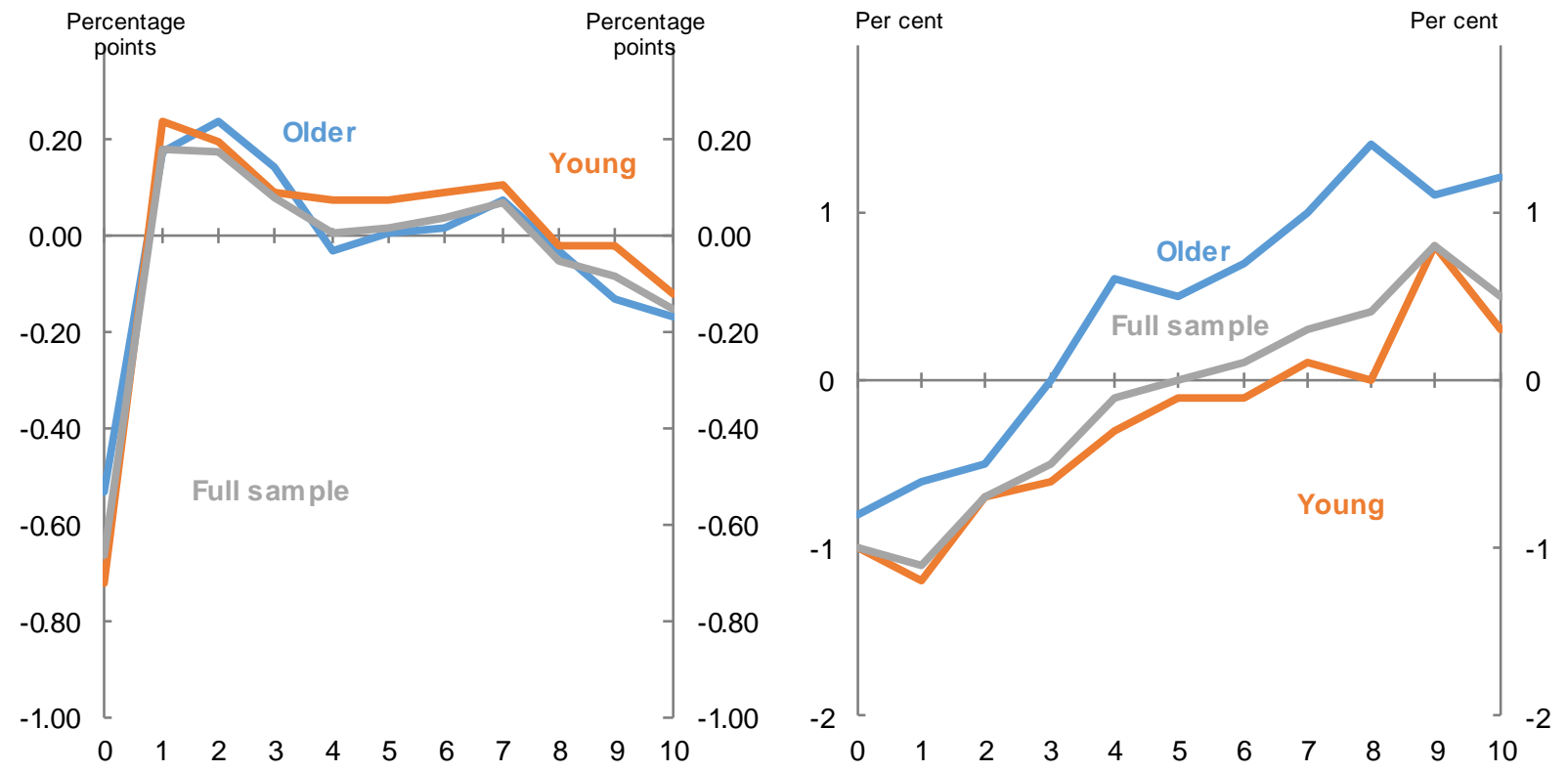

Note: Shows estimated effect of a 1 percentage point increase in the state-youth unemployment rates, on switching rates and the productivity of employers, for various sub-samples. These come from the static model outlined in Section 5. Young are graduates under 25 years old. Older are graduates over 25 .

67. Interestingly, there also appear to be gender differences in these underlying mechanisms, which may explain the different experiences of labour market scarring. Women typically switch jobs less frequently than men, a fact previously observed in the tax data (Deutscher 2019). They also appear to switch less often than men in the aftermath of graduating into bad labour market (Figure 10, Panel A) and initially receive a poorer quality initial match as indicated by the lower productivity of the firm they join (Figure 10, Panel B). While they appear to recover in terms of the labour productivity of the firm they are matched to, it may be their reduced tendency to switch (which could reflect a wide variety of constraints) that leads them to be trapped in a lower productivity firm for longer, thus leading to more persistent scarring. 
Figure 10. Effect of a 1 percentage point increase in the local youth unemployment rate by years since graduation

Panel A: Effect on switching rates

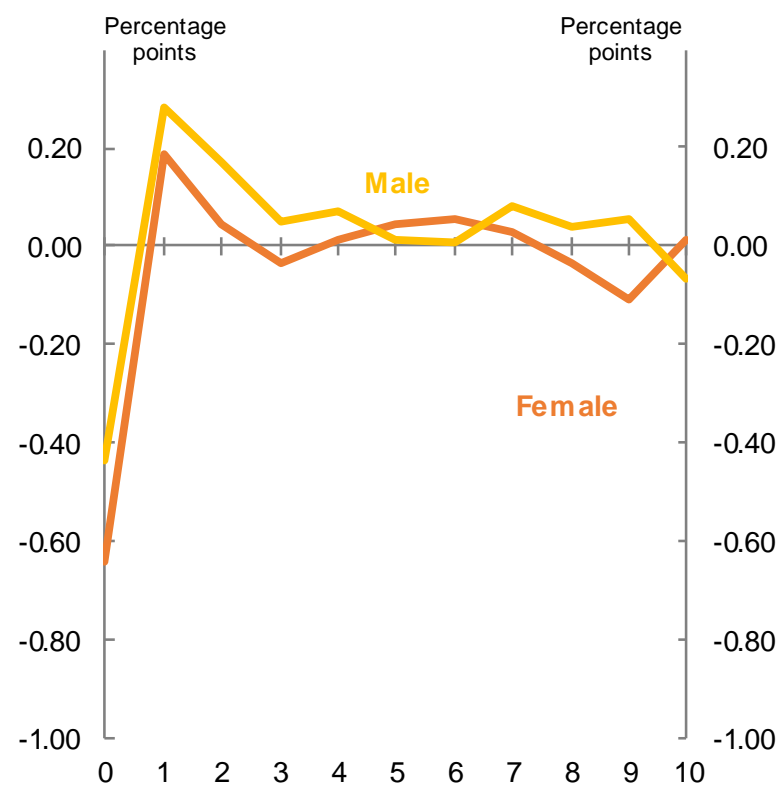

Panel B: Effect on employer productivity

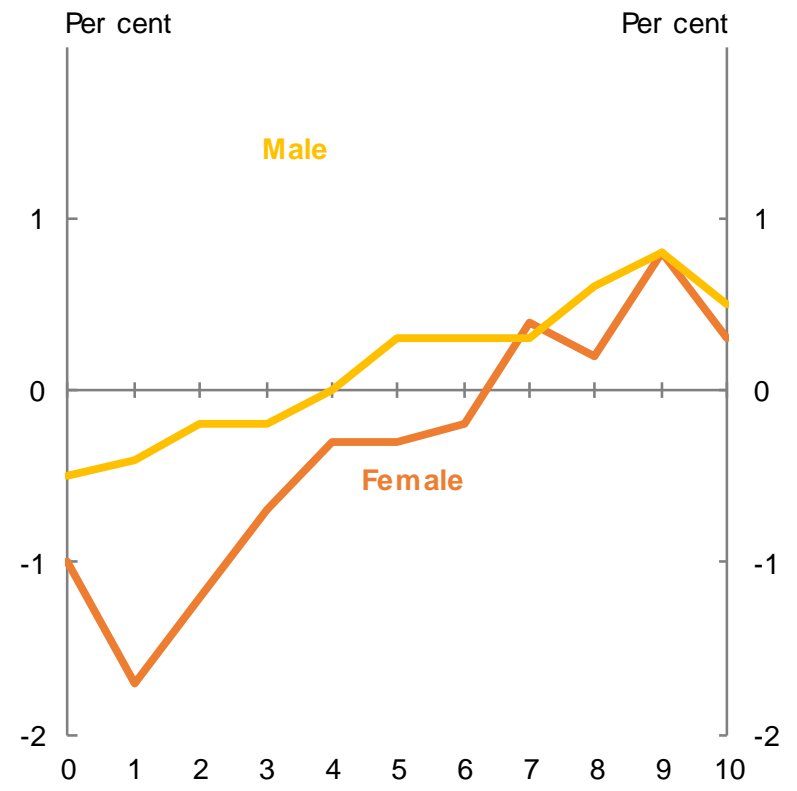

Note: Shows estimated effect of a 1 percentage point increase in the state-youth unemployment rates, on switching rates and the productivity of employers, for various sub-samples. These come from the static model outlined in Section 5.

\subsection{Are job ladders harder to find?}

68. Firm-worker matches seem to play an important role in both the initial hit to earnings for those graduating into weaker labour markets, and also in the recovery process. As noted earlier, this recovery process seems less robust for graduates of the 2000s than it was for those for those of the 1990s, with labour market scarring more persistent for more recent graduates. A natural place to look for an explanation is in the ease and efficiency with which workers are able to switch jobs.

69. A number of recent pieces have highlighted that measures of job-switching and labour market dynamism have declined over recent decades in Australia, with implications for productivity (Andrews and Hansell 2019) and wages (Deutscher 2019). Moreover, these declines appear to be particularly large for young, highly educated workers (Montaigne forthcoming; Figure 11), consistent with the idea that the ability of university graduates to undo poor initial matches may have declined.

70. This further highlights the importance in trying to understand the decline in labour market dynamism documented in Australia. Ongoing Treasury research examines a range of explanations, such as demographic change (Montaigne forthcoming) and better matching that lowers the need to switch jobs (Bradshaw forthcoming). Future research that examines other explanations, such as product and labour market competition and firm dynamism, could yield valuable insights for a number of reasons:

- First, new firms create scope for job switching by providing workers with new outside options but there has been a structural decline in the firm entry rates and young firm employment share.

- Second, young workers are more likely to be employed at young firms (Andrews 2019; Ouimet and Zarutskie 2014).

- Third, much of the decline in the aggregate job switching rate in Australia appears to reflect a reduction in worker transitions from mature firms to young firms (Quinn, 2019). 
71. But it is also possible that heightened risk aversion and uncertainty could be relevant to the decline in job switching (Lowe, 2018; Foster and Guttman, 2018), suggesting further research on this area could be relevant for understanding the longer run effects of short run shocks.

\section{Figure 11. Job-switching rates by age group and educational attainment}

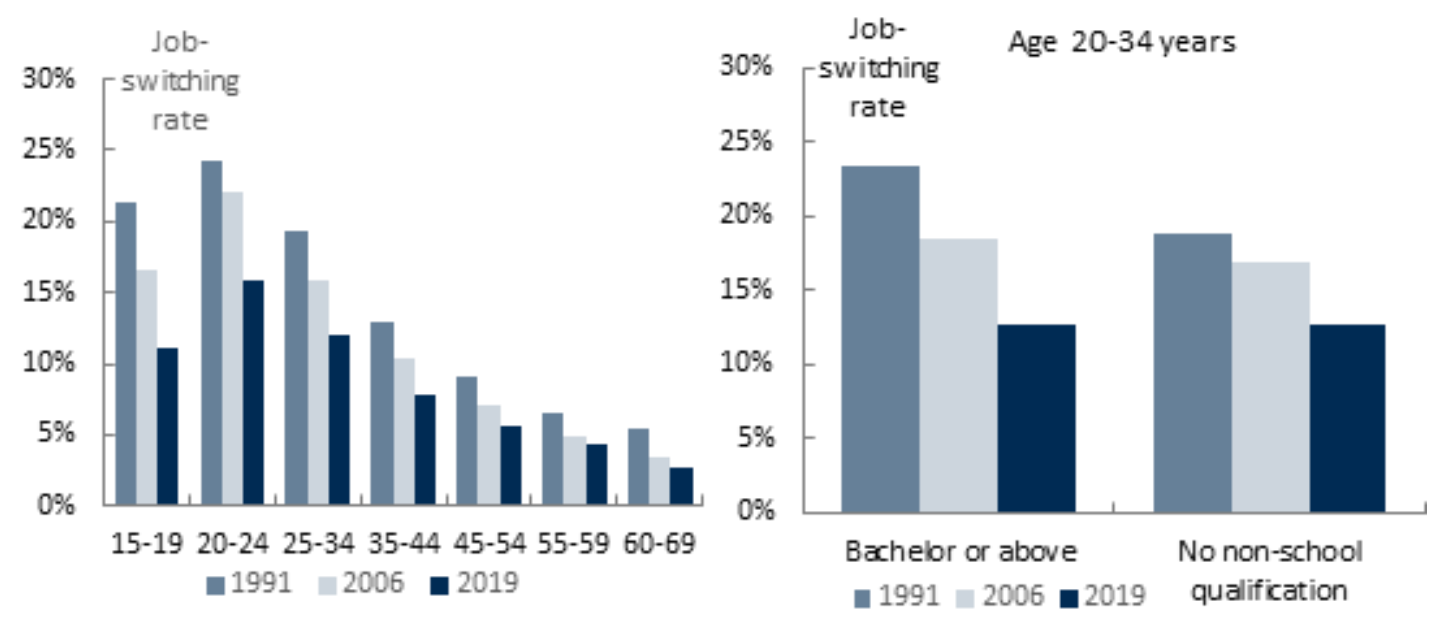

Source: Treasury analysis of ABS Participation, Job Search and Mobility, Australia (cat. No. 6226.0), various years; Montaigne (forthcoming).

\section{Conclusion}

72. Recent empirical studies spanning North America, Japan, United Kingdom and Europe show that individuals who enter the labour market during downturns experience scarring effects that can reduce their earnings for up to ten years after graduation. The global economic fallout from the COVID-19 pandemic, with associated sharp rise in unemployment rates, makes such findings particularly pertinent. In this paper, we find evidence for this phenomenon in the Australian setting. Our baseline results that imply that a 5 percentage point rise in the state youth unemployment rate - a typical contractionary episode in our data - is associated with declines in earnings and the employment-to-population ratio of an 8 and $3 \frac{1}{2}$ per cent respectively in the initial year. The implied loss then declines to $31 / 2$ and $3 / 4$ per cent respectively after five years, before fading to around zero ten years on. Importantly, we show that these results cannot be explained away by: i) selection effects which induce further education or migration due to the state of the business cycle; and ii) controlling for the future path of the unemployment rate.

73. Overall, a picture emerges whereby shocks that hit workers at the start of their careers are more important than those that hit later. But we also uncover heterogeneous effects. First, scarring is less prevalent for graduates with Honours/Postgraduate degrees (than a bachelor's degree) and from Group of Eight universities (than from other universities). This is consistent with international evidence which shows that those with higher expected earnings are less vulnerable to shocks. Second, older graduates, who may already have a foothold in the labour market, are less affected by scarring. Third, scarring is more modest for young individuals who do not attend university (compared to university graduates), which suggests that the scarring mechanism underlying our results relates to poor match quality and/or human capital depreciation. Fourth, female graduates experience more persistent labour market scarring. Finally, scarring effects are more prominent and permanent for individuals who graduated after 2000.

74. A key channel underpinning our results is the propensity for adverse cyclical shocks to disrupt the efficiency of the matching process. We show that graduates, especially young women, who enter the labour market during downturns initially find work (or remain in work) at lower productivity — and thus lower paying 
- firms. Over time, however, this negative firm productivity differential shrinks, which underpins the process of earnings recovery, given the strong link between worker wages and firm productivity (Treasury 2017; Andrews et al, 2019).

75. Labour market dynamism is a key mechanism underlying this catch-up process. While individuals that graduate in weaker economic times initially have lower job switching rates, switching rates eventually rise relative to the control group, which allows such workers to move to higher productivity firms and better paying jobs. A key implication is that factors which supress labour market dynamism will make it more difficult to underdo the damage of initial poor match quality and thus exacerbate scarring effects, potentially explaining two sources of heterogeneity. First, in the aftermath of graduating into weak labour market, women switch jobs less frequently than men, which may explain why scarring effects are more persistent for women. Second, there has been a structural decline in job switching rates over the past 30 years, which may explain why scarring effects are more prominent since 2000.

76. To the extent that we have provided a credible account of the scarring process, then what are the policy implications of our work?

77. First, our results - while only focused on a subset of the workforce - lend further support for the notion that structural factors may have weighed on wage growth in Australia (Andrews et al, 2019). One consequence of lower labour market dynamism is that young workers that graduated into the softer youth labour markets evident during and after the GFC may have remained in lower productivity, lower wage jobs for longer. This would have weighted on wages and productivity growth, and would be consistent with the idea that the response of wages to improved labour market conditions has been slower and more muted than in past cycles (MYEFO, 2018). Given the relatively persistent effects on wages, this is therefore relevant from a macroeconomic forecasting perspective. The results may also provide an argument in support of timely and well-designed counter-cyclical macroeconomic policies to cushion the effect on workers (Rothstein 2019) which is particularly relevant given the COVID-19 shock that is currently propagating onto the Australian economy.

78. Second, while the decline in labour market dynamism is likely to exacerbate the scarring effects from graduating in a downturn, it is also relevant for understanding why productivity growth has slowed in Australia. In this regard, perhaps one-quarter of the slowdown in market sector labour productivity growth since 2012 reflects the declining likelihood that more productive firms expand and less productive firms shed labour or exit (Andrews and Hansell, 2019). While there are plausible reasons for why declining market dynamism may be innocuous, it is also consistent with a rise in adjustment frictions - including barriers to labour mobility and competition - that slow down firm responsiveness. High priority should be placed on investigating these potential frictions as the decline in reallocation from less productive to more productive firms is holding down overall productivity growth. It also implies that fewer high paying jobs are being created than otherwise, given that high-productivity firms pay higher wages.

79. Finally, our work highlights the potential for structural reforms that reduce barriers to labour mobility and competition to enhance the labour market's capacity to absorb shocks, thereby enhancing macroeconomic resilience. This suggests a powerful complementarity between macroeconomic and structural policy in ameliorating the short- and longer-run impacts of macroeconomic shocks on workers. 


\section{References}

Altonji, J.G., Kahn, L.B. and Speer, J.D., 2016. Cashier or consultant? Entry labor market conditions, field of study, and career success. Journal of Labor Economics, 34(S1), pp.S361-S401.

Andrews, D., 2019. Comments on 'Dynamism diminished: The role of housing markets and credit conditions', Remarks at OECD Global Forum on Productivity, Sydney, 20-21 June 2019

Andrews, D., Deutscher, D., Hambur, J. and Hansell, D., 2019, Wage Growth in Australia: Lessons from Longitudinal Microdata, Treasury Working Paper No. 2019-04, The Treasury, Australian Government.

Andrews, D. and Hansell, D., 2019. Productivity-enhancing labour reallocation in Australia. Treasury Working Paper No. 2019-06. The Treasury, Australian Government.

ABS (Australian Bureau of Statistics), 2019, Migration, Australia, 2017-18, 'Net overseas migration, Arrivals, departures and net, State/territory, Age and sex - Calendar years, 2004 onwards', cat. no. 3412.0, accessed 24 February 2020, <http://stat.data.abs.gov.au/>.

Ball, L.M., 2009. Hysteresis in unemployment: old and new evidence. NBER Working Paper No. 14818, National Bureau of Economic Research.

Blanchard, O. and Summers.L., 1986. Hysteresis and the European Unemployment Problem, NBER Macroeconomics Annual 1986(1), pp.15-90.

Brell, C. and Dustmann, C., 2019, July. Immigration and wage growth: The case of Australia. In Paper for the RBA's Low Wage Growth Conference, Sydney.

Borland, J. and Coelli, M., 2020. Is it 'dog days' for the young in the Australian labour market, unpublished manuscript.

Borland, J. 2020. Scarring effects: A small piece of Australian evidence and a review of some main literature, Labour market snapshot \#58, 20 April 2020, unpublished.

Brunner, B. and Kuhn, A., 2014. The impact of labor market entry conditions on initial job assignment and wages. Journal of Population Economics, 27(3), pp.705-738.

Davis S.J. and Haltiwanger J.C., 2019. Dynamism diminished: The role of housing markets and credit conditions, NBER Working Paper No. 25466, National Bureau of Economic Research.

Deutscher, N., 2019. Job-to-job transitions and the wages of Australian worker. Treasury Working Paper No. 2019-07, The Treasury, Australian Government.

Dhillon, Z. and Cassidy, N., 2018. Labour Market Outcomes for Younger People. RBA Bulletin, June.

Fernald, J.G., Hall, R.E., Stock, J.H. and Watson, M.W., 2017. The disappointing recovery of output after 2009. NBER Working Paper No. 23543, National Bureau of Economic Research.

Foster, G. and Stratton, L.S., 2018. Do significant labor market events change who does the chores? Paid work, housework, and power in mixed-gender Australian households. Journal of Population Economics, 31(2), pp.483-519.

Foster, J and Guttmann, R. 2018, 'Perceptions of Job Security in Australia', RBA Bulletin, March 2018

Genda, Y., Kondo, A. and Ohta, S., 2010. Long-term effects of a recession at labor market entry in Japan and the United States. Journal of Human resources, 45(1), pp.157-196.

Hershbein B.J., 2012. Graduating High School in a Recession: Work, Education, and Home Production, The B.E. Journal of Economic Analysis \& Policy 12(1), pp. 1-32. 
Hombert, J. and Matray, A. 2019, Technology Boom, Labor Reallocation, and Human Capital Depreciation, HEC Paris Research Paper No. FIN-2018-1294.

Kahn, L.B., 2010. The long-term labor market consequences of graduating from college in a bad economy. Labour economics, 17(2), pp.303-316.

Kawaguchi, D. and Kondo, A., 2020. The Effects of Graduating from College during a Recession on Living Standards. Economic Inquiry, 58(1), pp.283-293.

Kroft K, Lange F and Notowidigdo M.J. 2013. Duration dependence and labour market conditions: Evidence from a field experiment, The Quarterly Journal of Economics, 128(3), pp.1123-1167.

Krueger A.B. and Mueller A.I. 2016. A contribution on the empirics of reservation wages, American Economic Journal: Economic Policy, 8(1), pp.142-179.

Kwon, I., Milgrom, E.M. and Hwang, S., 2010. Cohort effects in promotions and wages evidence from Sweden and the United States. Journal of Human Resources, 45(3), pp.772-808.

Lowe P., 2018, 'Productivity, Wages and Prosperity', Address to Australian Industry Group, Melbourne, 13 June 2018

Malmendier U. and Nagel S., 2011. Depression babies: Do macroeconomic experiences affect risk taking?, The Quarterly Journal of Economics, 126(1),pp.373-416.

McLaughlin, K.J. and Bils, M., 2001. Inter-industry mobility and the cyclical upgrading of labor. Journal of Labor Economics, 19(1), pp.94-135.

Murphy, K.M and Welch, F., 1990. Empirical Age-Earnings Profiles, Journal of Labor Economics 8(2), pp. 202-229.

OECD (Organisation for Economic Co-operation and Development), 2016. Society at a glance 2016.

Oreopoulos, P., Von Wachter, T. and Heisz, A., 2012. The short-and long-term career effects of graduating in a recession. American Economic Journal: Applied Economics, 4(1), pp.1-29.

Ouimet, P. and Zarutskie, R., 2014. Who works for startups? The relation between firm age, employee age, and growth. Journal of financial Economics, 112(3), pp.386-407.

PC (Productivity Commission), 2018. Rising inequality? A stocktake of the evidence. Productivity Commission Research Paper, Productivity Commission, Australian Government.

Quinn, M. 2019. What's driving low wages growth in Australia? Speech to the Australian Conference of Economists, Melbourne, 16 July 2019.

Raaum, O. and Røed, K., 2006. Do business cycle conditions at the time of labor market entry affect future employment prospects? The Review of Economics and Statistics, 88(2), pp.193-210.

Rothstein, J. 2019 The Lost Generation? Scarring after the Great Recession. Unpublished manuscript.

Schoar, A. and Zuo, L., 2017. Shaped by booms and busts: How the economy impacts CEO careers and management styles. The Review of Financial Studies, 30(5), pp.1425-1456.

Schwandt, H. and von Wachter T., 2019, Unlucky cohorts: Estimating the long-term effect of entering the labor market in a recession in large cross-section datasets, Journal of Labor Economics, 37(S1), pp.161-198.

Topel, R.H. and Ward, M.P., 1992. Job mobility and the careers of young men. The Quarterly Journal of Economics, 107(2), pp.439-79.

Treasury, 2017. Analysis of Wage Growth, Department of the Treasury, Australian Government.

Wozniak, A., 2010. Are college graduates more responsive to distant labor market opportunities? Journal of Human Resources, 45(4), pp.944-970.

Yagan, D., 2019. Employment hysteresis from the great recession. Journal of Political Economy, 127(5), pp.2505-2558. 


\section{Annex A. Summary Statistics}

Table A.1. Average summary statistics for wage and salary income by state, 1991-2017.

\begin{tabular}{|c|c|c|c|c|}
\hline Mean & Median & P25 & P75 & N Obs \\
\hline \multicolumn{5}{|c|}{ New South Wales } \\
\hline 40,502 & 34,124 & 17,175 & 53,444 & $2,984,900$ \\
\hline \multicolumn{5}{|c|}{ Victoria } \\
\hline 37,869 & 33,020 & 16,426 & 50,468 & $2,289,695$ \\
\hline \multicolumn{5}{|c|}{ Queensland } \\
\hline 36,502 & 32,101 & 15,964 & 49,135 & $1,756,923$ \\
\hline \multicolumn{5}{|c|}{ South Australia } \\
\hline 35,130 & 31,982 & 16,203 & 47,708 & 670,715 \\
\hline \multicolumn{5}{|c|}{ Western Australia } \\
\hline 40,433 & 34,073 & 16,227 & 54,891 & 947,306 \\
\hline \multicolumn{5}{|c|}{ Tasmania } \\
\hline 33,063 & 30,370 & 14,763 & 45,524 & 204,349 \\
\hline \multicolumn{5}{|c|}{ Northern Territory } \\
\hline 40,116 & 36,963 & 18,515 & 55,137 & 86,064 \\
\hline \multicolumn{5}{|c|}{ Australian Capital Territory } \\
\hline 45,548 & 42,319 & 21,287 & 62,284 & 179,230 \\
\hline
\end{tabular}

Source: ALIFE tax data.

Table A.2. Average number of graduates by gender and state, 1991 to 2017

\begin{tabular}{|c|c|c|c|c|c|c|c|}
\hline \multicolumn{2}{|c|}{ New South Wales } & \multicolumn{2}{|c|}{ Victoria } & \multicolumn{2}{|c|}{ Queensland } & \multicolumn{2}{|c|}{ South Australia } \\
\hline Female & Male & Female & Male & Female & Male & Female & Male \\
\hline 23,374 & 16,460 & 20,642 & 14,167 & 15,851 & 10,178 & 5,683 & 3,806 \\
\hline \multicolumn{2}{|c|}{ Western Australia } & \multicolumn{2}{|c|}{ Tasmania } & \multicolumn{2}{|c|}{ Northern Territory } & \multicolumn{2}{|c|}{ Australian Capital Territory } \\
\hline Female & Male & Female & Male & Female & Male & Female & Male \\
\hline 7,620 & 5,220 & 1,429 & 913 & 723 & 391 & 1,958 & 1,519 \\
\hline
\end{tabular}

Source: ALIFE tax data merged with HECS/HELP data; Treasury calculations. 
Figure A.1. Number of Graduates: Tax data versus Department of Education data

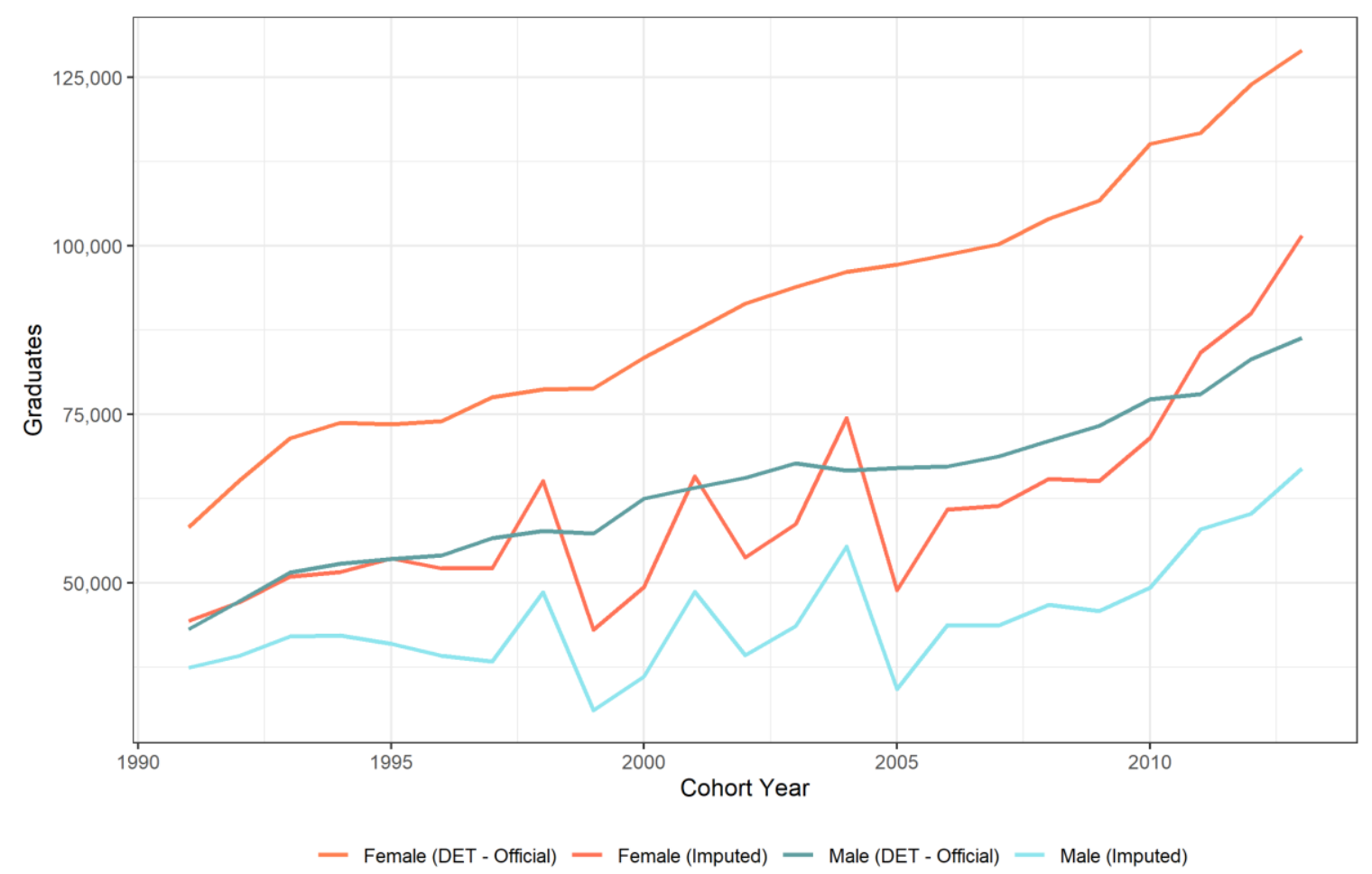

Note: 'HECS — Imputed' series show the number of graduates based on the imputed tax microdata. 'DET — Official' show the total number of domestic student graduation in each year, based on the Department of Education data:

https://docs.education.gov.au/documents/2017-section-14-award-course-completions.

Figure A.2. Deviation of state youth unemployment rate from national rate De-meaned; percentage point deviation

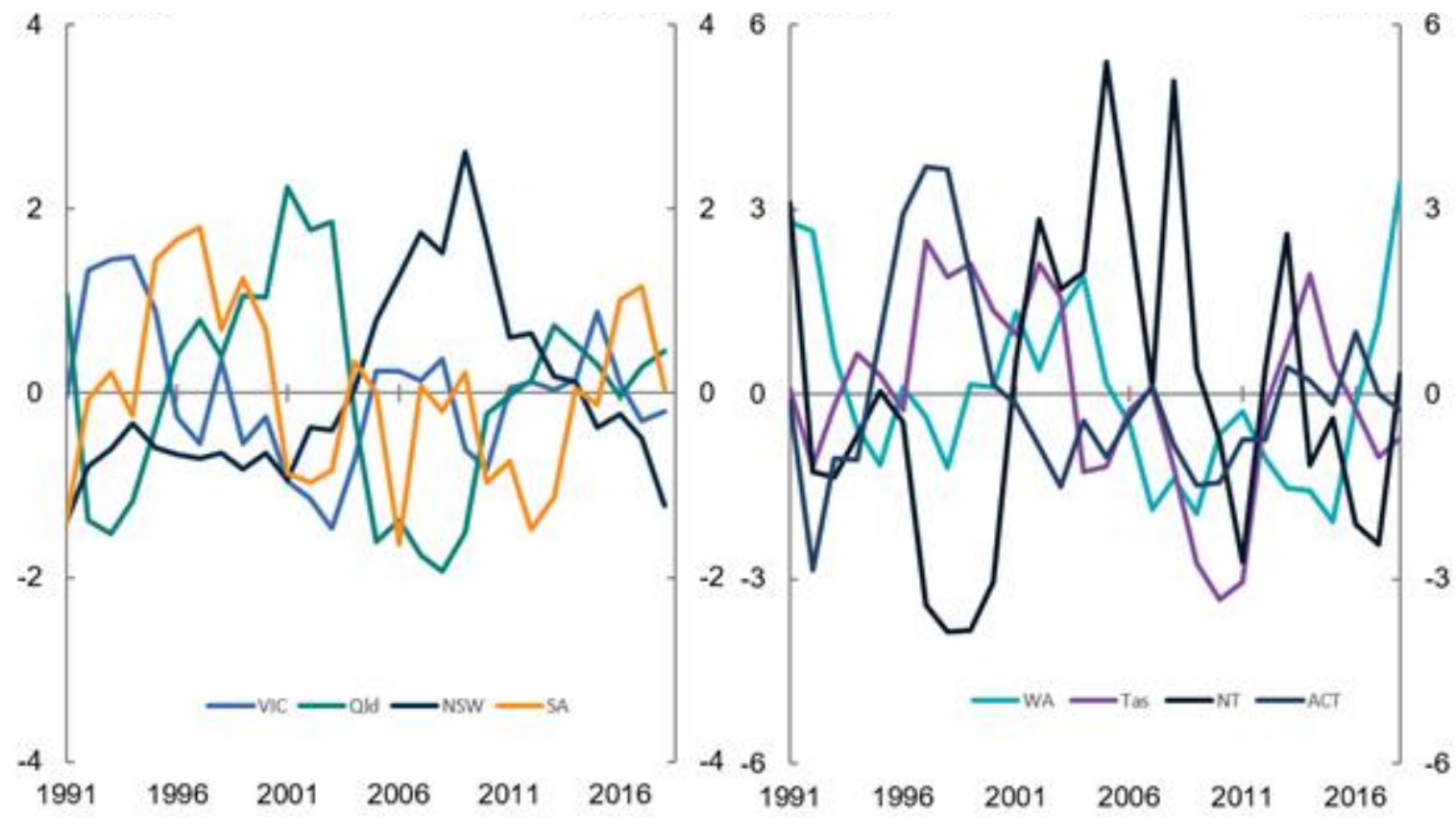

Source: ABS Labour Force Release Cat No. 6202.0. 


\section{2}

Figure A.3. Young Workers Share of Workforce by Firm Age

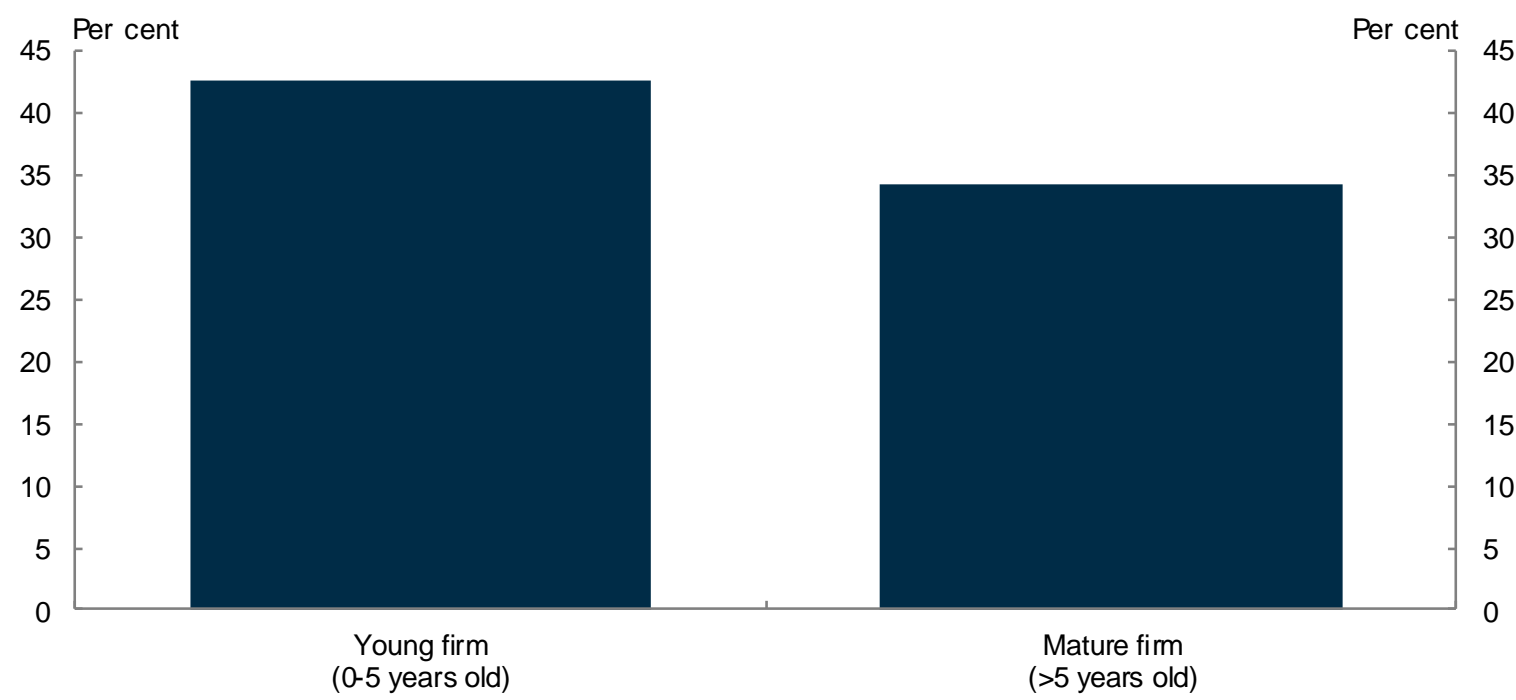

Note: Young Workers defined as those 30 years or less.

Source: Andrews (2019). 


\section{Annex B. Non-graduate results}

\section{Table B.1. Effect of a 1 percentage point increase in the youth unemployment rate on annual earnings and employment for graduates and non graduates}

\begin{tabular}{|c|c|c|c|c|}
\hline \multirow[b]{2}{*}{ Years since graduation } & \multicolumn{2}{|c|}{ Wages (\%) } & \multicolumn{2}{|c|}{ Employment rate (ppt) } \\
\hline & Baseline & Non-graduate & Baseline & Non-graduate \\
\hline 0 & $\begin{array}{c}-1.6^{\star \star *} \\
(0.2)\end{array}$ & $\begin{array}{c}-1.7^{* \star *} \\
(0.2)\end{array}$ & $\begin{array}{c}-0.69^{\star * *} \\
(0.05)\end{array}$ & $\begin{array}{c}-0.37^{\star * *} \\
(0.2)\end{array}$ \\
\hline 5 & $\begin{array}{c}-0.7^{\star \star \star} \\
(0.2)\end{array}$ & $\begin{array}{c}0.2 \\
(0.3)\end{array}$ & $\begin{array}{c}-0.13^{\star \star \star} \\
(0.05)\end{array}$ & $\begin{array}{l}-0.11 \\
(0.2)\end{array}$ \\
\hline 10 & $\begin{array}{l}-0.2 \\
(0.2)\end{array}$ & $\begin{array}{l}-0.2 \\
(0.2)\end{array}$ & $\begin{array}{l}0.10^{* *} \\
(0.05)\end{array}$ & $\begin{array}{l}-0.13 \\
(0.13)\end{array}$ \\
\hline $\begin{array}{l}\text { Specification } \\
\text { Experience FE X cohort FE } \\
\text { Cohort FE }\end{array}$ & $\begin{array}{l}x \\
x\end{array}$ & $\begin{array}{l}x \\
x\end{array}$ & $\begin{array}{l}x \\
x\end{array}$ & $\begin{array}{l}x \\
x\end{array}$ \\
\hline $\mathrm{N}$ & 2008 & 2008 & 2008 & 2008 \\
\hline
\end{tabular}

Note: Shows the coefficients on youth unemployment rate at graduation, at zero, five and ten years post-graduation. Based on a regression of mean log annual earnings or proportion of employed workers on the youth unemployment rate in the state and year of graduation, with year, state, experience and experience-cohort fixed effects. Standard errors, clustered at the state-cohort level, are presented in brackets.

1. Comparing wage outcomes for graduates and non-graduates (columns one and two of table A1) the initial effect of entering a weak labour market on wages is roughly equivalent: -1.6 and -1.7 per cent, respectively, for a one percentage point increase in the youth unemployment rate. However, the initial impact on the probability of employment (columns three and four) is more muted for non-graduates relative to graduates.

2. While the graduates' wage and employment outcomes are still statistically significantly lower five years post-graduation, there is no such evidence for non-graduates. This might suggest that some of the mechanisms through which weak labour markets affect worker outcomes are less relevant for non-graduates. For example, they may be less likely to lose out from a bad initial match. This could reflect non-graduates being more likely to work in less cyclical industries, meaning they may not may not experience any 'cyclical downgrading' in their employment, or more generally matching being less important in these industries. Alternatively, if the degree field chosen was closely related to the structure of the economy years prior to the downturn, graduates might be more prone to skills mismatches during downturn.

3. That said, the results could also reflect the greater difficulty in defining labour market entry for non-graduates. To the extent that our assumptions around labour market entry are off, this could introduce noise and bias the coefficients towards zero. 


\section{Annex C. Dynamic Model}

4. Figure $\mathrm{C} 1$ contains the results of the dynamic models that account for future unemployment rates. The 'Baseline' line uses the static model, while 'Group_01 (no history)' uses the same model, but with the average youth unemployment rate over years 0 and 1 to be more consistent with the groupings used in the dynamic models. This is the "Not controlling for later unemployment' series shown in the body of the paper'. Comfortingly, this shift to averaging youth unemployment rates over the first two years has no meaningful effect on the results. The 'Group_01 (state*year)' series comes from the model including state*time fixed effects to capture contemporaneous conditions, while Group_01 and Group_45 come from the full dynamic model, and trace out the effects of initial unemployment rates, and unemployment rates 4-5 years into a career. The former is the 'Controlling for later unemployment' series in the paper.

\section{Figure C.1. Effect of a 1 percentage point increase in the local youth unemployment rate by years since graduation}

Panel A: Effect on wages

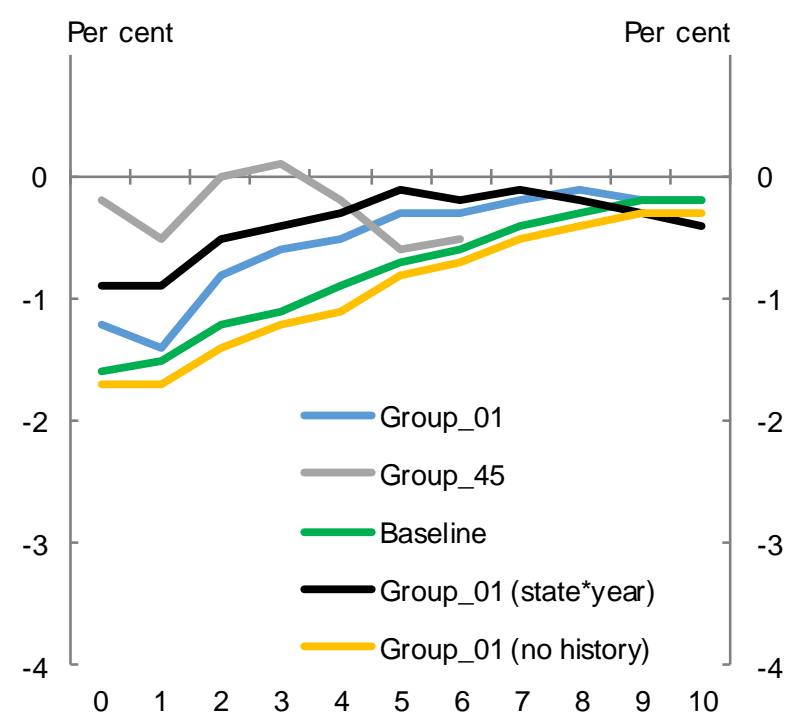

Panel B: Effect on employment

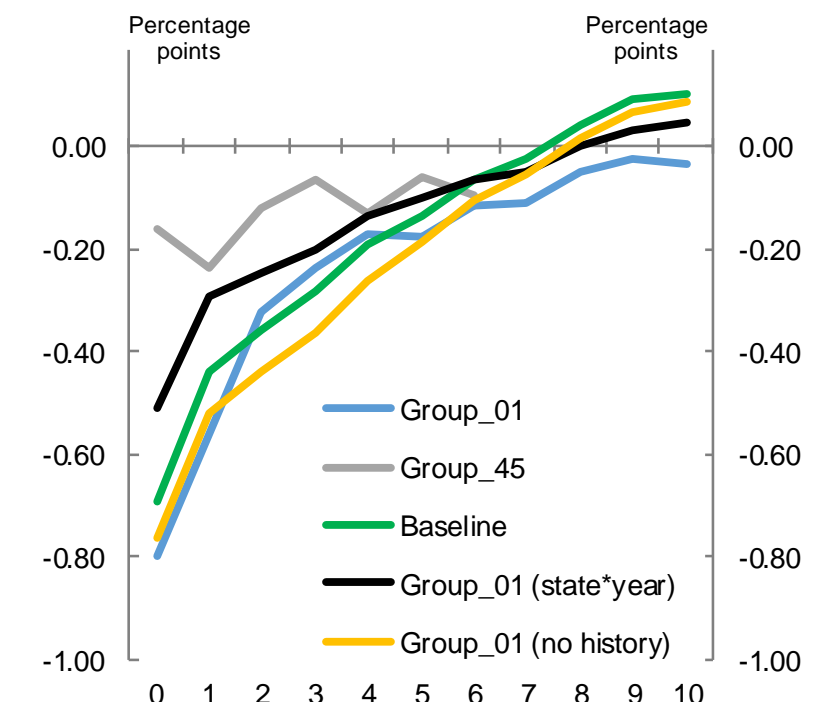

Note: Shows estimated effect of a 1 percentage point increase in the state youth unemployment rates on wages and employment from various models. Baseline is taken from the baseline static model outlined in section 5. Group_01 (no history) is taken from the same model, where the unemployment rate at graduation is replaced with the rate over the initial and first subsequent year. Group_01 (state*year) is from the same model, but including state*year fixed effects to capture the effects of later local economic conditions. Group_01 and Group_45 come from the full dynamic model, which incorporates the full labour market history of groups and allows these rates to have dynamic effects. Group_01 traces out the effect of the unemployment rate experienced in year 0 and 1. Group_45 traces out the effect of the unemployment rate experience in year 4 and 5.

5. The key takeaways from the dynamic models are as follows. Once we account for later conditions, the importance of the initial youth unemployment rate is diminished somewhat for both the wage and 
employment margins. In our preferred specification (Group_01), which is similar to the one used in Oreopolos et al (2012), the effect is reduced by about $1 / 3$ in each of the first five years for wages, and by slightly less for employment. However, there still appears to be a significant and persistent effect of initial unemployment rates for around 4-5 years following graduation.

6. The other main takeaway is that shocks that hit workers at the start of their careers are more important than those that hit a few years into the career. This is evident by the smaller and less persistent effect of unemployment rates 4-5 years later (Group_45) on both wages and employment. It indicates that what we are identifying is not simply the fact that weak labour markets are bad for all workers. Rather, what we are picking up is that they are particularly damaging for new graduates. 


\section{Annex D. Heterogeneous Effects}

Table D.1. Effect of a 1 percentage point increase in the youth unemployment rate on annual earnings for different groups (\%)

\begin{tabular}{|c|c|c|c|c|c|c|c|c|c|c|c|}
\hline \multirow[b]{2}{*}{ Years since graduation } & \multirow[t]{2}{*}{ Baseline } & \multicolumn{2}{|c|}{ G8 University } & \multicolumn{2}{|c|}{ Course Level } & \multicolumn{2}{|c|}{ Gender } & \multicolumn{2}{|c|}{ Age } & \multicolumn{2}{|c|}{ Cohort period } \\
\hline & & Non--G8 & G8 & Bachelor & Hounours+ & Female & Male & Younger & Older & Pre-2000 & Post-2000 \\
\hline 0 & $\begin{array}{c}-1.6^{* * *} \\
(0.2)\end{array}$ & $\begin{array}{c}-2.0^{* * *} \\
(0.2)\end{array}$ & $\begin{array}{c}-1.1^{* * *} \\
(0.4)\end{array}$ & $\begin{array}{c}-1.7^{* * *} \\
(0.2)\end{array}$ & $\begin{array}{c}-1.1^{* * *} \\
(0.4)\end{array}$ & $\begin{array}{c}-1.5^{* * * *} \\
(0.2)\end{array}$ & $\begin{array}{c}-1.8^{* * *} \\
(0.3)\end{array}$ & $\begin{array}{c}-2.1^{* * *} \\
(0.2)\end{array}$ & $\begin{array}{c}-0.8^{* * *} \\
(0.3)\end{array}$ & $\begin{array}{c}-1.6^{* * *} \\
(0.3)\end{array}$ & $\begin{array}{c}-0.8^{* * *} \\
(0.3)\end{array}$ \\
\hline 5 & $\begin{array}{c}-0.7^{* * *} \\
(0.2)\end{array}$ & $\begin{array}{c}-0.7^{* * *} \\
(0.2)\end{array}$ & $\begin{array}{l}-0.4^{*} \\
(0.3)\end{array}$ & $\begin{array}{c}-1.0^{* * *} \\
(0.2)\end{array}$ & $\begin{array}{c}0.2 \\
(0.4)\end{array}$ & $\begin{array}{c}-0.7^{* * *} \\
(0.2)\end{array}$ & $\begin{array}{c}-0.6^{* * *} \\
(0.2)\end{array}$ & $\begin{array}{c}-0.9^{* * *} \\
(0.2)\end{array}$ & $\begin{array}{c}-0.4^{* * *} \\
(0.2)\end{array}$ & $\begin{array}{c}0.1 \\
(0.2)\end{array}$ & $\begin{array}{c}-1.1^{* * *} \\
(0.2)\end{array}$ \\
\hline 10 & $\begin{array}{c}-0.2 \\
(0.2)\end{array}$ & $\begin{array}{l}-0.2 \\
(0.2)\end{array}$ & $\begin{array}{c}0.2 \\
(0.2)\end{array}$ & $\begin{array}{c}-0.8^{* * *} \\
(0.2)\end{array}$ & $\begin{array}{c}0.4 \\
(0.4)\end{array}$ & $\begin{array}{l}-0.4^{* *} \\
(0.2)\end{array}$ & $\begin{array}{c}0.1 \\
(0.2)\end{array}$ & $\begin{array}{c}-0.6^{* * *} \\
(0.2)\end{array}$ & $\begin{array}{l}0.3^{* *} \\
(0.2)\end{array}$ & $\begin{array}{c}-0.3 \\
(0.0002)\end{array}$ & $\begin{array}{c}-0.6^{* *} \\
(0.2)\end{array}$ \\
\hline $\begin{array}{l}\text { Specification } \\
\text { Experience FE X cohort FE }\end{array}$ & $\mathrm{x}$ & $x$ & $x$ & $x$ & $x$ & $x$ & $x$ & $x$ & $x$ & $x$ & $x$ \\
\hline Cohort FE & $x$ & $x$ & $x$ & $x$ & $x$ & $x$ & $x$ & $x$ & $x$ & $x$ & $x$ \\
\hline $\mathrm{N}$ & 2008 & 2008 & 2008 & 2008 & 2008 & 2008 & 2008 & 2008 & 2008 & 1046 & 944 \\
\hline
\end{tabular}

Note: Shows the coefficients on youth unemployment rate at graduation, at zero, five and ten years post graduation. Based on a regression of mean log annual earnings on the youth unemployment rate in the state and year of graduation, with year, state, experience and cohort fixed effects. Estimated over different sub samples of the population. Standard errors, clustered at the state cohort level, are presented in brackets. ${ }^{* * *},{ }^{* * *}$ indicate statistical significance at the 10,5 and 1 per cent level, respectively. 


\title{
OECD PRODUCTIVITY WORKING PAPERS
}

\author{
OECD Productivity Working Papers are published on oe.cd/GFP
}

05. The Best versus the Rest: The Global Productivity Slowdown, Divergence across Firms and the Role of Public Policy (November 2016) by Dan Andrews, Chiara Criscuolo and Peter N. Gal

06. What makes cities more productive? Agglomeration economies and the role of urban governance: Evidence from 5 OECD countries

(February 2017) by Rudiger Ahrend, Emily Farchy, loannis Kaplanis and Alexander C. Lembcke

07. Pro-Productivity Institutions: Learning From National Experience (April 2017) by Andrea Renda and Sean Dougherty

08. The impact of structural reforms on productivity: The role of the distance to the technological frontier

(May 2017) by Gustavo Monteiro, Ana Fountoura Gouveia and Sílvia Santos

09. Product markets' deregulation: A more productive, more efficient and more resilient economy?

(September 2017) by Gustavo Monteiro, Ana Fountoura Gouveia and Sílvia Santos

10. Achieving New Zealand's productivity potential (October 2017) by Paul Conway

11. The Contribution of Multinational Enterprises to Labor Productivity: The Case of Israel (February 2018) by Tatiana Slobodnitsky, Lev Drucker and Assaf Geva

12. GVCs and centrality: mapping key hubs, spokes and the periphery (February 2018) by Chiara Criscuolo and Jonathan Timmis

13. Fear the walking dead: zombie firms, spillovers and exit barriers (June 2018) by Ana Fontoura Gouveia and Christian Osterhold

14. GVC centrality and productivity: Are hubs key to firm performance? (June 2018) by Chiara Criscuolo and Jonathan Timmis

15. Patterns of firm level productivity in Ireland (September 2018) by Javier Papa, Luke Rehill and Brendan O'Connor

16. Productivity spillovers from multinational activity to local firms in Ireland (November 2018) Mattia Di Ubaldo, Martina Lawless and Iulia Siedschlag

17. Unconventional monetary policy and productivity (January 2019) Silvia Albrizio, Marina Conesa, Dennis Dlugosch and Christina Timiliotis

18. Industry concentration in Europe and North America (January 2019) Matej Bajgar, Giuseppe Berlingieri, Sara Calligaris, Chiara Criscuolo and Jonathan Timmis

19. Productivity and innovation at the industry level: What role for integration in global value chains?

(October 2019)Peter Gal and William Witheridge 


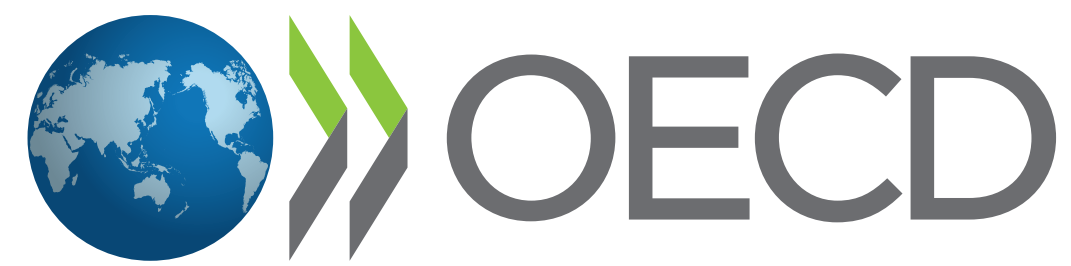

BETTER POLICIES FOR BETTER LIVES 